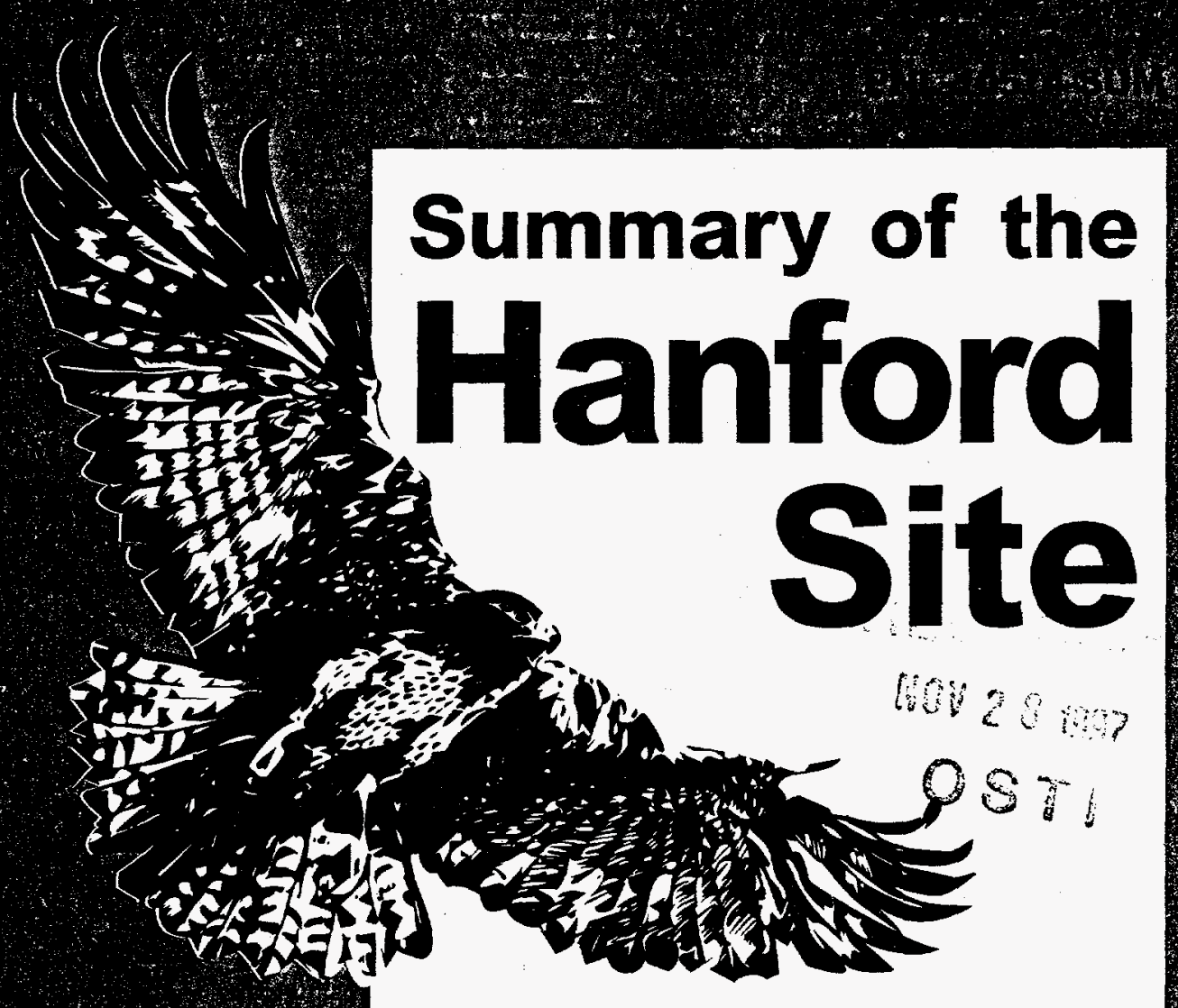

Environmental Report 1994 
PNL-10574-SUM

\title{
Summary of the Hanford Site Environmental Report for Calendar Year 1994
}

\author{
Compiled and Edited by \\ R.W. Hanf \\ R.E. Schrempf \\ R.L. Dirkes \\ January 1996
}

DISCLAIMER

This report was prepared as an account of work sponsored by an agency of the United States Government. Neither the United States Government nor any agency thereof, nor any of their employees, makes any warranty, express or implied, or assumes any legal liability or responsibility for the accuracy, completeness, or usefulness of any information, apparatus, product, or process disclosed, or represents that its use would not infringe privately owned rights. Reference herein to any specific commercial product, process, or service by trade name, trademark, manufacturer, or otherwise does not necessarily constitute or imply its endorsement, recommendation, or favoring by the United States Government or any agency thereof. The views and opinions of authors expressed herein do not necessarily state or reflect those of the United States Government or any agency thereof. 


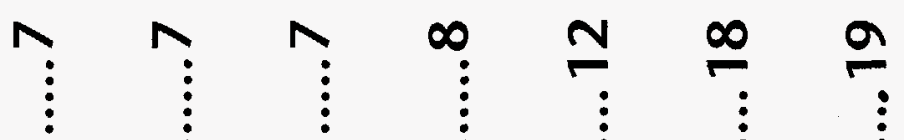
๑ 응
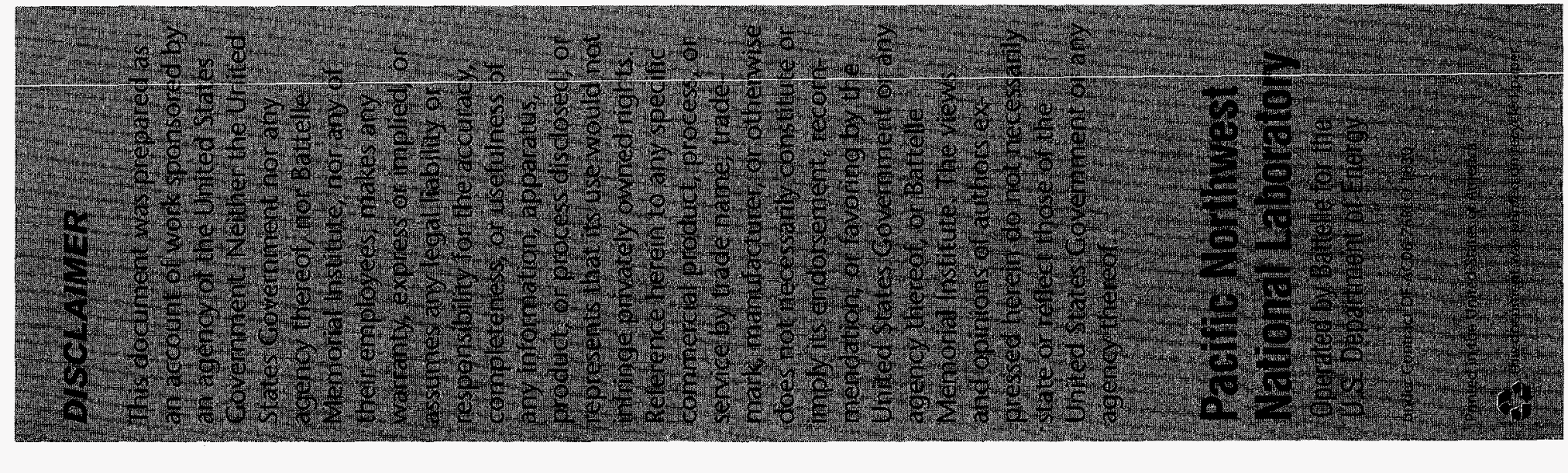


\section{DISCLAMIIR}

Portions of this doecoment may be illegible in electronic image products. Ingeges are produced from the best available origional document. 


\section{Environmental Report 1994 Summary}

\section{Introduction}

This booklet summarizes the 390-page Hanford Site Environmental Report for Calendar Year 1994. The Hanford Site Environmental Report is prepared annually to review and document environmental data and information, describe environmental management performance, and demonstrate the status of compliance with environmental regulations. The report also highlights major environmental programs and efforts and is written to meet both the reporting requirements and guidelines of the U.S. Department of Energy (DOE) and the needs of the public. This booklet includes information on important Hanford Site compliance issues, environmental monitoring programs and results, and general information on the Site and the surrounding area.

Unlike summary pamphlets for previous years, this summary for 1994 includes some scientific data, technical terms, and units of measurement. However, technical jargon, acronyms, and references are avoided whenever possible. Readers interested in more detailed information can consult the complete 1994 report or the technical documents cited and listed therein. Copies of the full report have been provided to many public libraries in communities around the Hanford Site and to several university libraries in Washington and Oregon. Copies of the report can be purchased from the National Technical Information Center, Springfield, Virginia 22161 and can be accessed on the Internet at http://w3.pnl.gov:2080/env/env_home.html.

Inquiries about this summary booklet, or comments and suggestions about its content, may be directed to the DOE Richland Operations Office, Quality, Safety, and Health Programs Division, P.O. Box 550, Richland, Washington 99352, or to Mr. Roger Dirkes, Pacific Northwest National Laboratory, P.O. Box 999, Richland, Washington 99352. 


\section{Overview of the Hanford Site and Historical Operations}

The Hanford Site lies within the semiarid Pasco Basin of the Columbia Plateau in southeastern Washington State (Figure 1). The Site occupies an area of about $1,450 \mathrm{~km}^{2}$ (approximately $560 \mathrm{mi}^{2}$ ) located north of the City of Richland and the confluence of the Yakima River with the Columbia River. This large area has restricted public access and provides a buffer for the smaller areas onsite that historically were used for production of nuclear materials, waste storage, and waste disposal. Only about $6 \%$ of the land area has been disturbed and is actively used. The Columbia River flows eastward through the northern part of the
Hanford Site and then turns south, forming part of the eastern boundary. The Yakima River flows along part of the southern boundary and joins the Columbia River downstream from the city of Richland. Land in the surrounding environs is used for urban and industrial development, irrigated and dry-land farming, and grazing. The cities of Richland, Kennewick, and Pasco (Tri-Cities) constitute the nearest population center and are located southeast of the Site.

The Hanford Site was established in 1943 to use technology that was developed at the University of Chicago and the Clinton Laboratory in Oak Ridge, Tennessee to produce plutonium for some

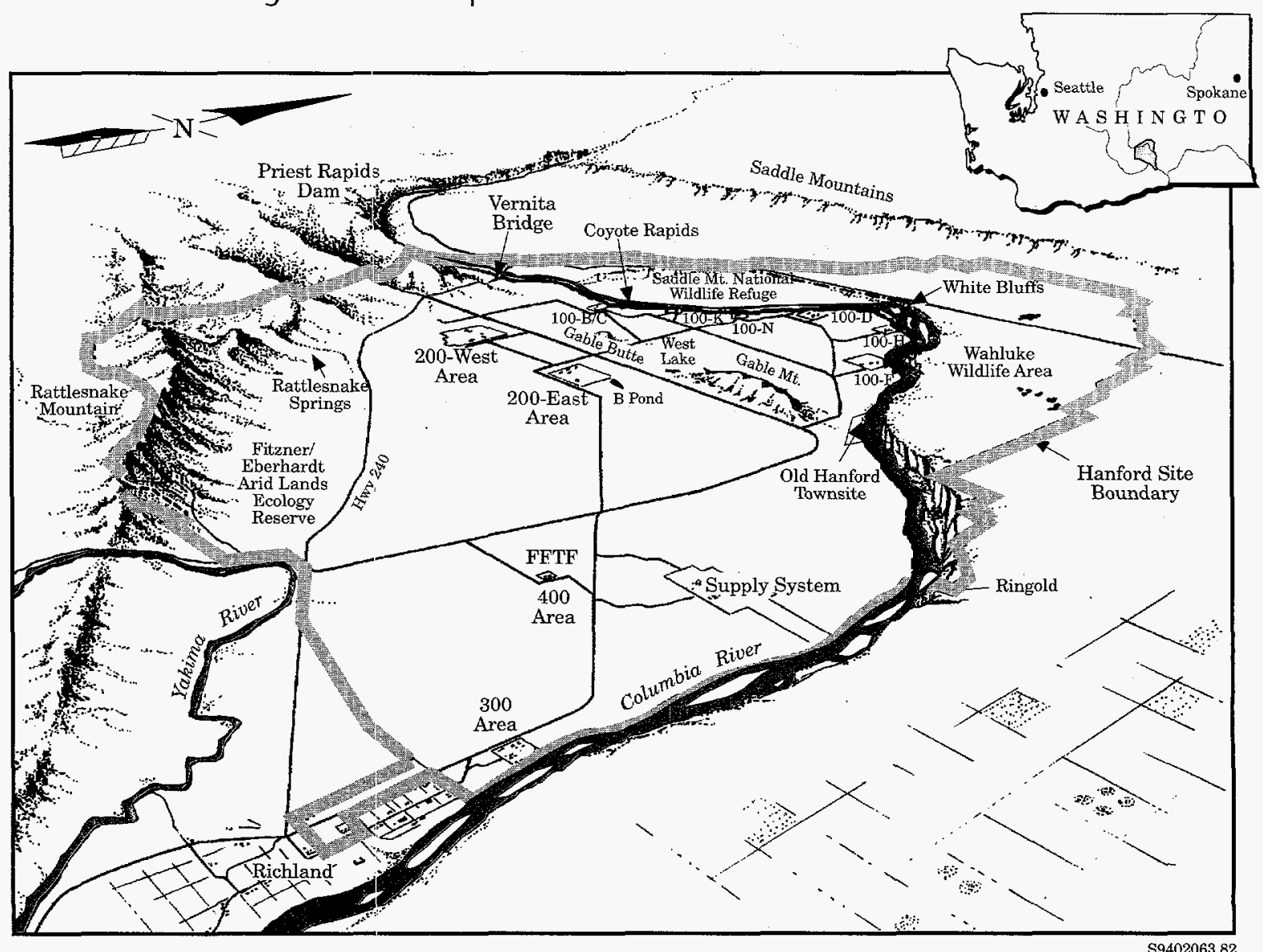

Figure 1. DOE's Hanford Site and Surrounding Area. 


\section{Environmental Report 1994 Summary}

of the nuclear weapons tested and used in World War II. Hanford was the first plutonium production facility in the world. Nearly all technology was developed as it was needed. The site was selected by the U.S. Army Corps of Engineers because it was remote from major populated areas and had ample electrical power from Grand Coulee Dam, a functional railroad, clean water available from the nearby Columbia River, and sand and gravel available onsite that could be used for constructing large concrete structures. For security, safety, and functional reasons the Site was divided into areas that were numbered (Figure 1).

Hanford operations have resulted in the production of liquid, solid, and gaseous wastes. Most wastes resulting from Site operations have had at least the potential to contain radioactive materials. From an operational standpoint, radioactive wastes were categorized as "high level," "intermediate level," or "low level." Beginning in 1970 , most high level solid wastes were segregated according to the makeup of the waste material, packaged in special containers, and stored in trenches that were covered with soil (this segregation and packaging did not occur before 1970). Some high level solid waste, such as large pieces of machinery and equipment, were placed onto railroad flatcars and stored in underground tunnels. Both intermediate and low level solid wastes consisting of tools, machinery, paper, wood, etc. were placed into covered trenches at storage and disposal sites known as "burial grounds." High level liquid wastes were stored in large underground tanks. Intermediate level liquid waste streams were usually routed to underground structures of various types called "cribs." Occasionally, trenches were filled with the liquid waste and then covered with soil after the waste had soaked into the ground. Low level liquid waste streams were usually routed to surface impoundments (ditches and ponds). Nonradioactive solid wastes were usually burned in "burning grounds." This practice was discontinued in the late 1960s in response to the Clean Air Act, and the materials were instead buried at sanitary landfill sites. These storage and disposal sites, with the exception of high level waste tanks, are designated as "active" or "inactive" waste sites, depending on whether or not the site currently is receiving wastes.

\section{The $\mathbf{3 0 0}$ Area}

From the early 1940 s to the present, most research and development activities at the Hanford Site were carried out in the 300 Area, located just north of Richland. The 300 Area was also the location of nuclear fuel fabrication. Nuclear fuel in the form of pipe-like cylinders ("fuel slugs") was fabricated from metallic uranium shipped in from offsite production facilities. Metallic uranium was extruded into the proper shape and encapsulated in aluminum or zirconium cladding. Copper was an important material used in the extrusion process, and substantial amounts of copper, uranium, and other heavy metals ended up in 300 Area liquid waste streams. In more recent times, the low level liquid wastes were shipped to a solar evaporation facility in the $100-\mathrm{H}$ Area (100-H Area Basins).

\section{The 100 Areas}

The fabricated fuel slugs were shipped by rail from the 300 Area to the 100 Areas. The 100 Areas are located on the shore of the Columbia River, where up to nine nuclear reactors were in operation. The main part of the nuclear reactors consisted of a large stack ("pile") 


\section{Hanford Site}

of graphite blocks that had tubes and pipes running through it. The tubes housed the fuel slugs while the pipes carried cooling water that was eventually returned to the Columbia River. The large collection of slightly radioactive uranium in the reactor piles resulted in an extensive radiation field and a radioactive chain reaction that caused some uranium atoms to be converted into plutonium atoms. Other uranium atoms were split into radioactive "fission products." The intense radiation field also caused atoms in the structure to become radioactive "activation products."

The first eight reactors, constructed between 1944 and 1955, used water from the Columbia River for direct cooling. Large quantities of water were pumped through the piles and discharged back into the River. The discharged cooling water contained small amounts of radioactive materials that escaped from the fuel slugs, tube walls, etc. during the irradiation process. The radiation field in the pile also caused some of the impurities in the river water to become radioactive ("neutron activation"). The ninth reactor, $N$ Reactor, was completed in 1963 and was of a slightly different design. Purified water was recirculated through the reactor core in a closed-locp cooling system. Beginning in 1966, the heat from the closedloop system was used to produce steam that was sold to the Washington Public Power Supply System to generate electricity at the adjacent Hanford Generating Plant.

When fresh fuel was pushed into the front face of a reactor's graphite pile, irradiated fuel slugs were forced out the rear into a deep pool of water called a "fuel storage basin." After a brief period of storage in the basin and further storage in special freight cars on a railroad siding, the irradiated fuel was transported by rail to the
200 Areas where the plutonium was recovered. Most of the irradiated fuel produced at $N$ Reactor from the mid-1970s to late 1983 was transported by rail car to the 100-K East and 100-K West fuel basins for "temporary" storage, where it remains today.

\section{The 200 Areas}

The 200 East and 200 West Areas are located on a plateau about $11 \mathrm{~km}$ and $8 \mathrm{~km}$ (7 and $5 \mathrm{mi}$ ), respectively, south of the Columbia River. These areas housed facilities that received and dissolved irradiated fuel and then separated out the valuable plutonium. These facilities were called "separations plants." Three types of separations plants were used over the years to process irradiated fuel. Each of the plutonium production processes used a feed stock derived from the dissolution of the aluminum or zirconium cladding material in ammonium hydroxide followed by the dissolution of the irradiated fuel slugs in nitric acid. Each of the three separations plants therefore produced large quantities of waste nitric acid solutions containing high levels of radioactive materials. These wastes were neutralized and stored in large underground tanks. Fumes from the dissolution of cladding and fuel, and other plant processes, were discharged to the atmosphere from tall smokestacks, which were filtered after 1950 .

Both B Plant and T Plant used the "bismuth phosphate" process to precipitate and separate plutonium from acid solutions during the early days of Hanford operations. Leftover uranium and high level waste products were not separated and were stored together in large underground "single-shell" tanks, i.e., tanks constructed with a single wall of steel. The leftover uranium was later salvaged, purified into uranium oxide powder at 


\section{Environmental Report 1994 Summary}

the Uranium-TriOxide (UO-3) Plant, and transported to uranium pro-duction facilities in other parts of the country for reuse. This salvage process used a solvent extraction technique that resulted in radioactive liquid waste that was disposed to ground in covered trenches at the B$C$ Cribs Area south of the 200 East Area. Cooling water from B Plant went to B Pond, cooling water from T Plant went to T Pond, and cooling water from U Plant and the Uranium-TriOxide Plant was routed to U Pond.

After T Plant was used as a separations facility it was converted to a decontamination operation where large pieces of equipment and machinery could be cleaned up for reuse. B Plant was later converted into a facility to separate radioactive strontium and cesium from high level waste. The strontium and cesium were then concentrated into a solid salt material, melted, and encapsulated at the adjacent Encapsulation Facility. Canisters of encapsulated strontium and cesium were stored in a water storage basin at the Encapsulation Facility.

The REDOX (reduction oxidation) Plant (200 West Area) and PUREX (plutonium-uranium extraction) Plant (200 East Area) used solvent extraction techniques to separate plutonium from leftover uranium and radioactive waste products. Most of the irradiated fuel produced at Hanford was processed at either of these two facilities. The solvent extraction method separates chemicals based on their differing solubilities in water and organic solvents, i.e., hexone at the REDOX Plant and tributylphosphate (TBP) at the PUREX Plant. High level liquid wastes were neutralized and stored in single-shell tanks (REDOX Plant) or double-shell tanks (PUREX Plant). Occasionally, organic materials such as solvents and resins ended up in high level liquid waste streams sent to the tanks. Because the solutions discharged to these tanks were not acidic, various chemicals and radioactive materials precipitated and settled to the bottom of the tanks. This phenomenon was later used to advantage - the liquid waste was heated in special facilities ("evaporators") to remove excess water and concentrate the waste into salt cake and sludge, which remained in the tanks. The evaporated and condensed water contained radioactive tritium and was discharged to cribs. Intermediate and low level liquid wastes discharged to ground from the REDOX and PUREX Plants typically contained tritium and other radioactive fission products as well as nonradioactive nitrate. Intermediate level liquid wastes discharged to cribs from the Redox Plant sometimes contained hexone used in the REDOX process. Cooling water from the Redox plant was discharged to the REDOX Ponds. Cooling water from the PUREX Plant was discharged to Gable Mountain Pond and B Pond.

The REDOX and PUREX Plants produced uranium nitrate for recycle and plutonium nitrate for weapon component production. Uranium nitrate was shipped by tank truck to the UraniumTriOxide Plant for processing. The UraniumTriOxide Plant used specially designed machinery to heat the uranium nitrate solution and boil off the nitric acid, which was recovered and recycled to the separation plants. The product, uranium oxide, was packaged and shipped to other facilities in the United States for recycle. Plutonium nitrate, in small quantities for safety reasons, was placed into special shipping containers ("P-R cans") and hauled by truck to the $Z$ Plant for further processing.

Plutonium was received at one of several buildings operated over the years that were 


\section{Hanford Site}

collectively known as Z Plant, now called the Plutonium Finishing Plant. The purpose of Z Plant operations was to convert the plutonium nitrate into plutonium metal blanks ("buttons") that were manufactured into nuclear weapons components. The conversion processes used nitric acid, hydrofluoric acid, carbon tetrachloride, and various oils and degreasers. Varying amounts of all these materials ended up in the intermediate level liquid wastes that were discharged to cribs. Cooling water from the Z Plant was discharged via open ditch to U Pond. High level wastes containing plutonium were segregated and packaged for storage in special earthcovered trenches.

\section{The 400 Area}

In addition to research and development activities in the 300 Area, the Hanford Site has supported several test facilities. The largest was the Fast Flux Test Facility (FFTF) located in the 400 Area, about $8 \mathrm{~km}(5 \mathrm{mi})$ northwest of the 300 Area. This special nuclear reactor was designed to test various types of nuclear fuel. The facility operated for about 13 years and was shut down in 1993. The reactor was a unique design that used liquid metal sodium as the primary coolant. The heated liquid sodium was cooled with atmospheric air in heat exchangers. Spent fuel from the facility resides in the 400 Area, while other wastes were transported to the 200 Areas. With the exception of the spent fuel, no major amounts of radioactive wastes were disposed of at the FFTF site.

\section{The 600 Area}

This area includes all of the Hanford Site not occupied by the $100,200,300,400,700$, 1100 , and 3000 Areas.

\section{Richland Areas}

Areas near the Site in north Richland provide Site support services. These include the 1100,3000 , and Richland North Areas. The 1100 Area is the location for general stores and transportation maintenance. The 3000 Area is the location for ICF Kaiser Hanford Company facilities. DOE and DOE contractor facilities located between the 300 Area and the city of Richland but outside the 1100 and 3000 Areas are located in the Richland North Area. The 700 Area includes federal facilities in downtown Richland.

\section{Other Areas}

Several areas of the Site have special designations. These total $665 \mathrm{~km}^{2}\left(257 \mathrm{mi}^{2}\right)$ and include the Fitzner/Eberhardt Arid Lands Ecology Reserve, the U.S. Fish and Wildlife Service Saddle Mountain National Wildlife Refuge, and the Washington State Department of Game Reserve Area (Wahluke Slope Wildlife Recreation Area).

\section{Non-DOE Operations}

Non-DOE operations and activities include commercial power production by the Washington Public Power Supply System's WNP-2 Reactor (near the 400 Area) and commercial low level radioactive waste burial at a site leased and licensed by the state of Washington and operated by US Ecology (near the 200 Areas). Siemens Power Corporation operates a commercial nuclear fuel fabrication facility, and Allied Technology Group Corporation operates a low level radioactive waste decontamination, supercompaction, and packaging disposal facility. Both are near the southern boundary of the Site. 


\section{Environmental Report 1994 Summary}

\section{The Hanford Site Mission}

The mission at the Hanford Site is no longer plutonium production and waste management. In recent years, programs at the Site have been realigned to emphasize cleanup and restoration as well as waste management.

The current Site mission includes:

- Management of Stored Waste from past activities and the handling, storage, and disposal of radioactive, hazardous, mixed, or sanitary wastes from current operations

- Environmental Restoration of approximately 1,100 inactive radioactive, hazardous, and mixed waste disposal sites and about 100 surplus facilities

- Research and Development in energy, health, safety, environmental sciences, molecular sciences, environmental restoration, waste management, and national security

\section{- Development of New Technologies for} environmental restoration and waste management, including site characterization and assessment methods, waste minimization, treatment, and remediation technology.

\section{Site Management}

Operations and activities on the Hanford Site are managed by the DOE Richland Operations Office through four prime contractors and numerous subcontractors.

The principal contractors are: Westinghouse Hanford Company (Operating and Engineering Contractor), Battelle Memorial Institute
(Research and Development Contractor), Bechtel Hanford Incorporated (Environmental Restoration Contractor), and Hanford Environmental Health Foundation (Occupational and Environmental Health Services Contractor).

\section{Regulatory Oversight}

The U.S. Environmental Protection Agency (EPA) is the principal federal environmental regulator at Hanford. In some instances, EPA has delegated environmental regulatory authority to the state or authorized the state program to operate in lieu of the federal program when the state's program meets or exceeds EPA's requirements. For instance, EPA has delegated or authorized enforcement authority to the Washington State Department of Ecology for air pollution control and many areas of hazardous waste management. In other activities, the state program is assigned direct oversight over federal agencies as provided by federal law. For example, the Washington State Department of Health has direct authority under the Clean Air Act to implement its state program for regulating radionuclide air emissions at the Hanford Site. Where regulatory authority is not delegated or authorized to the state, EPA Region 10 is responsible for reviewing and enforcing compliance with EPA regulations as they pertain to the Hanford Site.

Although the state of Oregon does not have a direct regulatory role at the Hanford Site, DOE recognizes its interest in Hanford Site cleanup because Oregon is located downstream along the Columbia River and there is the potential for radioactive wastes from the Hanford Site to be shipped through Oregon by rail, truck, or barge. Oregon participates in the State and Tribal Government Working Group for the Hanford Site, which reviews the Site's cleanup plans. 


\section{Hanford Site}

\section{The Role of Indian Tribes}

The Hanford Site is located on land ceded in 1855 by treaties with the Yakarna Indian Nation and the Confederated Tribes of the Umatilla Indian Reservation. The Nez Perce Tribe has treaty rights on the Columbia River. The tribes were guaranteed the right to fish "at all usual and accustomed places" and the privilege to hunt, gather roots and berries, and pasture horses and cattle on "open and unclaimed" land. The Wanapum people are not a federally recognized tribe and are therefore ineligible for federal programs. However, they have historical ties to the Hanford Site and are routinely consulted regarding cultural and religious freedom issues.

In addition to treaties, other lavss such as the American Indian Religious Freedom Act, the Archaeological Resources Protection Act, the National Historic Preservation Act, and the Native American Graves Protection and Repatriation Act provide a basis for the tribes' active participation in Hanford plans and activities.

\section{Public Participation}

Individual citizens of Washington State and neighboring states may influence Hanford Site cleanup decisions through public participation activities. The public is invited to share their input through many forums, including Hanford Advisory Board meetings, activities related to the Hanford Federal Facility Agreement and Consent Order (Tri-Party Agreement), National Environmental Policy Act meetings covering various environmental impact statemerts and environmental assessments, special forums to address specific Hanford decisions, and many less formal avenues.
Upcoming opportunities for public participation are announced in the bimonthly Hanford Update, a compilation of public involvement activities, and the monthly Hanford Happenings calendar, which highlights all scheduled meetings and comment periods.

Most of Hanford's public resides in Washington, Oregon, and Idaho. To provide the public better access to up-to-date Hanford information, four information repositories have been established. They are located in Richland, Seattle, and Spokane, Washington, and Portland, Oregon. In addition, the Washington State Department of Ecology and EPA maintain administrative records in Seattle and Richland.

Information about any Tri-Party Agreement public participation activity can be requested by calling 1-800-321-2008.

\section{Environmental Compliance}

The DOE Order 5400.1, "General Environmental Protection Program," describes the environmental standards and regulations applicable at DOE facilities.

A key element in Hanford's compliance program is the Tri-Party Agreement, which was signed in May 1989. This is an agreement among the EPA, Washington State Department of Ecology, and DOE for achieving compliance with the remedial action provisions of the Comprehensive Environmental Response, Compensation, and Liability Act (including Superfund Amendments and Reauthorization Act) and with treatment, storage, and disposal unit regulation and corrective action provisions of the Resource Conservation and Recovery Act. 


\section{Environmental Report 1994 Summary}

Negotiations to make major changes to the Tri-Party Agreement were conducted in 1993, and a renegotiated agreement was signed by the three agencies in January 1994. Further significant changes were negotiated during 1994. Copies of the agreement and Site Management System progress reports of activities are publicly available for inspection at the DOE Public Reading Room, Washington State University campus, Richland, Washington, and at information repositories in Seattle and Spokane, Washington, and Portland, Oregon. To be on the mailing list to obtain Tri-Party Agreement information, contact the EPA or DOE directly, or call The Washington State Department of Ecology at 1-800-321-2008. Requests can also be mailed to:

$\begin{array}{ll}\text { Hanford Mailing List: } & \text { or } \begin{array}{l}\text { Hanford Update } \\ \text { Informational Mailings }\end{array} \\ \text { Department of Ecology } \\ \text { P.O. Box 1970 B3-35 } & \text { P.O. Box 47600 } \\ \text { Richland, WA 99352 } & \text { Olympia, WA 98504-7600 }\end{array}$

\section{Comprehensive Environmental Response, Compensation, and Liability Act}

This Act established a program to ensure that sites contaminated by hazardous substances are cleaned up by responsible parties or the government. The Superfund Amendments and Reauthorization Act broadened the Comprehensive Environmental Response, Compensation, and Liability Act and established provisions for federal facilities. The Comprehensive Environmental Response, Compensation, and Liability Act primarily covers waste cleanup of inactive sites.

The preliminary assessments conducted for the Hanford Site revealed approximately 1,100 known individual waste sites where hazardous substances may have been disposed of in a manner that requires further evaluation to determine impact to the environment.

The DOE is actively pursuing the remedial investigation/feasibility study process at some operable units on the Hanford Site. Operable units currently under investigation were selected as a result of Tri-Party Agreement negotiations. The Hanford Site was in compliance with all Comprehensive Environmental Response, Compensation, and Liability Act/Superfund Amendments and Reauthorization Act requirements in 1994.

\section{Emergency Planning and Community Right-To-Know Act}

This Act requires that the public be provided with information about hazardous chemicals in the community and establishes emergency planning and notification procedures to protect the public from a release. Subtitle $A$ of the law calls for creation of state emergency response commissions to guide planning for chemical emergencies. State commissions have also created local emergency planning committees to ensure community participation and planning.

To provide the public with the basis for emergency planning, Subtitle B of the Act contains requirements for periodic reporting on hazardous chemicals stored and/or used near the community. During 1994, the Hanford Site was in compliance with the reporting and notification requirements contained in this Act.

\section{Resource Conservation and Recovery Act}

This Act established regulatory standards for the generation, transportation, storage, treat- 


\section{Hanford Site}

ment, and disposal of hazardous wastes. The Washington State Department of Ecology has been authorized by the EPA to implement its dangerous waste program in lieu of the EPA's for Washington State, except for some provisions of the Hazardous and Solid Waste Amendments of 1984. The Washington State Department of Ecology also implements the state's regulations, which are often more stringent. The Resource Conservation and Recovery Act primarily covers ongoing waste management at: active facilities.

At the Hanford Site, over 60 treatment, storage, and disposal units have been identified that must be permitted or closed in accordance with the Resource Conservation and Recovery Act and Washington State regulations. These units are required to operate under the Washington State Department of Ecology's interirn-status compliance requirements. Approximately one-half of the units will be closed.

Subtitle I of the Resource Conservation and Recovery Act deals with regulation of underground storage tank systems. These regulations were added to the Resource Conservation and Recovery Act by the Hazardous and Solid Waste Amendments of 1984. The EPA has developed regulations implementing technical standards for tank performance and management, including standards governing the cleanup and closure of leaking tanks. These regulations do not apply to the single- and double-shell nuclear waste tanks, which are regulated as treatment, storage, and disposal facilities.

\section{Clean Air Act}

The purpose of this Act is to protect public health and welfare by safeguarding air quality, bringing polluted air into compliance, and protecting clean air from degradation. In Washington State, the provisions of the Act are implemented by EPA, Washington State Department of Ecology, Washington State Department of Health, and local air authorities.

Washington State regulations require registration of all radioactive air emission point sources with the Washington State Department of Health. All significant Hanford Site stacks emitting radioactive materials have been registered in accordance with applicable regulations.

Revised Clean Air Act requirements for radioactive air emissions were issued in December, 1989, under National Emission Standards for Hazardous Air Pollutants. Emissions from the Hanford Site are well within the new EPA offsite emissions standard of $10 \mathrm{mrem} /$ year (effective dose equivalent). Hanford Site sources are in the process of meeting the procedural requirements for flow measurement, emissions measurement, quality assurance, and sampling documentation.

Pursuant to this program, EPA has developed regulations specifically addressing asbestos emissions. These regulations apply at the Hanford Site in building demolition/disposal and waste disposal operations. During 1994, $2,063 \mathrm{~m}^{3}\left(72,860 \mathrm{ft}^{3}\right)$ of asbestos were removed and properly disposed.

The Benton County Clean Air Authority, the local air authority, is responsible for enforcing Regulation 1, which pertains to detrimental effects, fugitive dust, incineration products, open burning, odor, opacity, and emissions. The Benton County Clean Air Authority also has been delegated responsibility to enforce the EPA asbestos regulations under the National Emission 


\section{Environmental Report 1994 Summary}

Standards for Hazardous Air Pollutants. The Site remains in compliance with the regulations.

\section{Clean Water Act}

This Act applies to point discharges to waters of the United States. At the Hanford Site, the regulations are applied through a National Pollutant Discharge Elimination System permit governing effluent discharges to the Columbia River. The permit specifies discharge points (called outfalls), effluent limitations, and monitoring requirements. In 1994, there were no instances of noncompliance for this permit.

\section{Safe Drinking Water Act}

The National Primary Drinking Water Regulations of this Act apply to the drinking water supplies at the Hanford Site. These regulations are enforced by the Washington State Department of Health. In 1994, all Hanford Site water systems were in compliance with requirements and agreements.

\section{Toxic Substances Control Act}

The application of Toxic Substances Control Act requirements to the Hanford Site essentially involves regulation of the chemicals called polychlorinated biphenyls (PCBs). The Hanford Site is currently in compliance with regulations for nonradioactive PCBs. All radioactive $\mathrm{PCB}$ wastes are being stored onsite pending development of treatment and disposal technologies and capabilities.

\section{Federal Insecticide, Fungicide, and Rodenticide Act}

This Act and the Revised Code of Washington, "Washington Pesticide Application Act, 1961," as implemented by Washington Administrative Code 16-228, "General Pesticides Regulations," apply to storage and use of pesticides. The EPA is responsible for ensuring that a chemical, when used according to label instructions, will not present unreasonable risks to human health or the environment. In 1994, the Hanford Site was in compliance with this federal Act and state regulations.

\section{Endangered Species Act}

A few rare species of native plants and animals are known to occur on the Hanford Site. Some of these are listed by the U.S. Fish and Wildlife Service as endangered or threatened (federally listed). Others are listed by the Washington Department of Fish and Wildlife as endangered, threatened, or sensitive species. Hanford Site activities complied with the Endangered Species Act in 1994.

\section{National Historic Preservation Act, Archaeological Resources Protection Act, Native American Graves Protec- tion and Repatriation Act, and Ameri- can Indian Religious Freedom Act}

Cultural resources on the Hanford Site are subject to the provisions of these Acts. Compliance with these Acts is accomplished through a management and monitoring program. In 1994, Hanford Site operations complied with these Acts.

\section{National Environmental Policy Act}

This Act established environmental policy to prevent or eliminate damage to the environment and to enrich our understanding of ecological systems and natural resources. The Act requires major federal projects to be carefully reviewed 


\section{Hanford Site}

for potential environmental impacts. Other National Environmental Policy Act documents such as environmental assessments are also prepared in accordance with Act requirements.

Several environmental impact statements related to programs or activities on the Hanford Site are in progress or in the planning stage.

\section{Environmental Occurrences}

Onsite and offsite environmental occurrences (spills, leaks, etc.) of radioactive and nonradioactive effluent materials during 1994 were reported to DOE as specified in DOE Orcler 5000.3B, and to other federal and state agencies as required by law. All emergency, unusual, and off-normal occurrence reports, including event descriptions and corrective actions, are available for review in the DOE Public Reading Room, Washington State University Tri-Cities campus, Richland, Washington. In 1994, no emergency occurrences were reported, and 33 unusual occurrences were reported. There were 16 off-normal environmental release-related occurrence reports filed at the Hanford Site during 1994.

\section{Current Issues and Actions}

\section{Hanford Federal Facility Agreement and Consent Order (Tri-Farty Agreement)}

Eighty-six milestones scheduled for 1994 were completed. At the end of 1994, a total of 378 enforceable Tri-Party Agreement milestones (for 1989 through 1994) had been completed on or ahead of schedule. Two milestones were missed, and two were completed later than scheduled.
A package of new negotiated changes to the Tri-Party Agreement was developed in January 1995. The new requirements will establish 65 new enforceable milestones and 32 new unenforceable target dates.

\section{Lawsuits Filed}

A lawsuit was filed against both the Site Operating and Engineering Contractor and DOE in early 1992. The suit alleged violations of the Clean Water Act resulting from discharges of pollutants without a permit and for failure to notify the appropriate agencies of releases of hazardous substances from high level waste tanks. The United States Court of Appeals for the Ninth Circuit dismissed this case in January 1995.

In July 1993, a class-action lawsuit was filed against the current Site Operating and Engineering Contractor and Westinghouse Electric Corporation in Yakima Superior Court in Yakima, Washington. The plaintiffs sought damages to provide medical monitoring and an injunction against further discharges to the environment. The federal court dismissed all claims against the current Operating and Engineering Contractor. DOE consolidated the defenses for litigation purposes.

\section{Submarine Reactor Compartments}

Eight defueled submarine reactor compartments were received and placed in Trench 94 in the 200-East Area during 1994. This brings the total number received to 43 . The reactor compartments are regulated by the Washington State Department of Ecology as dangerous waste because they contain lead used as shielding. They are also regulated by EPA because they contain small amounts of PCBs bound within 


\section{Environmental Report 1994 Summary}

the matrix of nonmetallic materials such as thermal insulation, electrical cables, and some synthetic rubber items.

\section{Environmental and Molecular Science Laboratory}

In 1994, ground was broken for the construction of the Environmental and Molecular Science Laboratory. When completed, the $18,600 \mathrm{~m}^{2}$ $\left(200,000 \mathrm{ft}^{2}\right)$ laboratory will accommodate up to 270 permanent staff, visiting scientists, postdoctoral researchers, and students who will work to develop the science and technology needed to clean up environmental problems at government and industrial sites nationwide. Research conducted at this national user facility is expected to lead to advancements in energy, new materials, health and medicine, and agriculture.

\section{Environmental Restoration}

Environmental restoration includes activities to decontaminate and decommission facilities, clean up inactive waste sites, and prevent the spread of contamination. In 1994, the Hanford Site Environmental Restoration Project Plan was completed, providing a program baseline that includes cost estimates for remedial design and remedial actions for the entire project and cost estimates for the decontamination and decommissioning of 170 facilities in the program.

The Decontamination and Decommissioning Program conducts surveillance and maintenance of surplus facilities and performs cleanup and demolition of facilities. In 1994, cleanup and demolition of 14 buildings was completed.
The Environmental Restoration Remedial Action Program was established to clean up about 1,100 inactive waste sites. In 1994, cleanup activities on the North (Wahluke) Slope and the Arid Lands Ecology Reserve were completed, making the land potentially available for other uses. In the 100 and 200 Areas, the program began test operations of five groundwater treatment systems that treated over $11,000 \mathrm{~m}^{3}$ ( 3 million gal) of water, and continued a soil vapor extraction system that removed about $41,000 \mathrm{~kg}(90,000 \mathrm{lb})$ of carbon tetrachloride from the soil. An expedited response action was approved for the N Springs site, and design and initial testing were started to reduce the flow of strontium-contaminated ground water to the river.

\section{0-K Area Fuel Storage Basins}

In February 1994, the Spent Nuclear Fuel Project was established. The project mission is to provide safe, economic, and environmentally sound management of Hanford spent nuclear fuel until final disposition.

The Hanford Site spent nuclear fuel inventory constitutes about $80 \%$ of the inventory currently stored in the DOE complex. The majority of Hanford's inventory consists of about 2,100 metric tons (2,300 tons) of irradiated $\mathrm{N}$ Reactor fuel stored in the $105 \mathrm{~K}$-East and $105 \mathrm{~K}$-West Fuel Storage Basins (K Basins) (Figure 2).

Decisions were made in 1994 that support a strategy for near-term and interim fuel storage of the K Basin inventory. This strategy supports removal of the fuel and sludge from the $\mathrm{K}$ Basins before December 2002, as stipulated in the Tri-Party Agreement. The Spent Nuclear Fuel Project is now in the process of implementing 


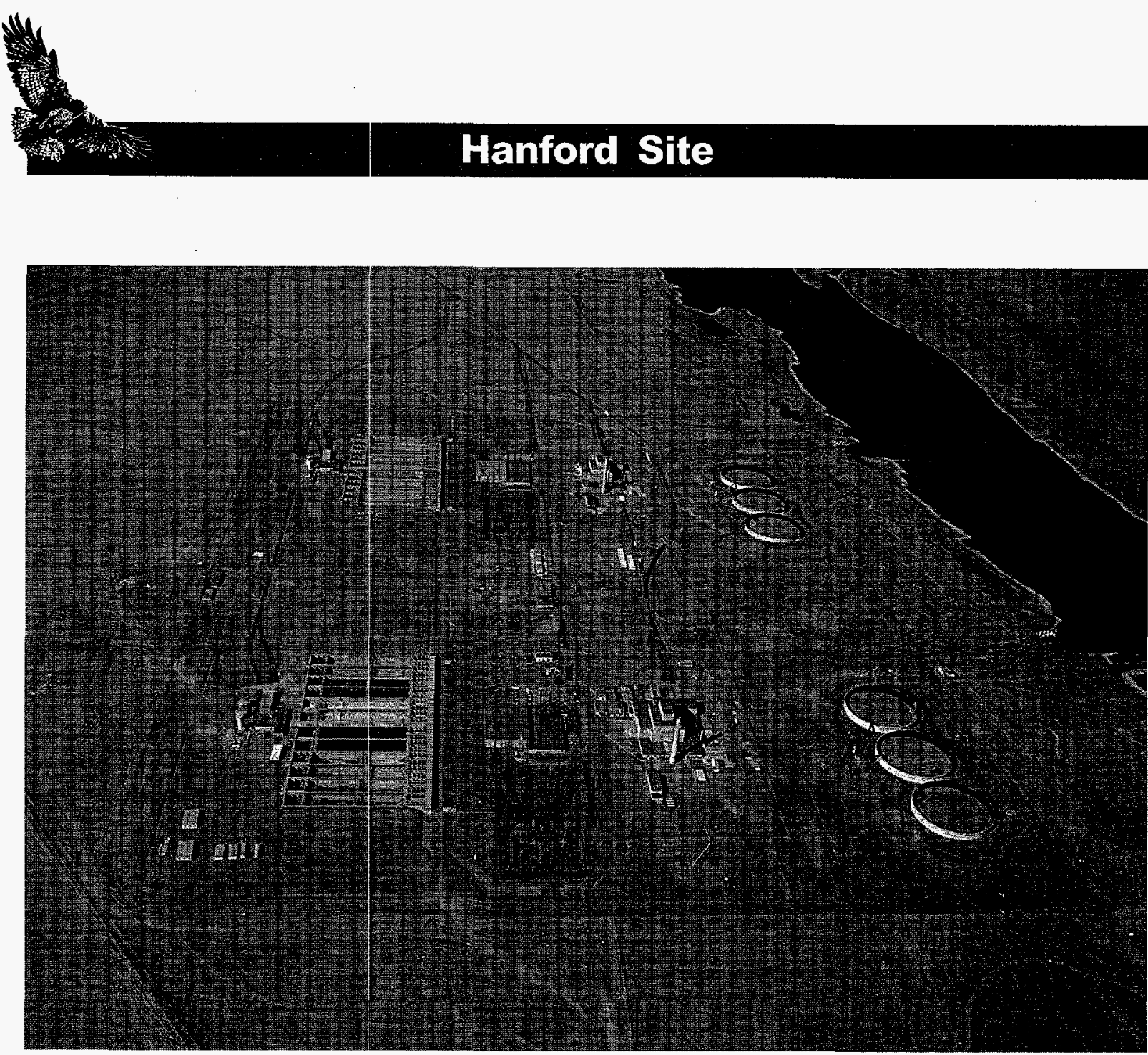

Figure 2. The Fuel Storage Basins ( $K$ Basins) are Located in the Reactor Buildings to the Left of the Circular Structures.

the strategy for accelerating the removal of fuel and sludge from the $K$ Basins.

In 1994, a project was started to install isolation barriers in the basins. These barriers will isolate the spent fuel from a vulnerable construction joint in the discharge chute of the basins. This action will prevent the shielding water from draining from the basins in the event of a major earthquake.

\section{Waste Vitrification}

Approximately $215,000 \mathrm{~m}^{3}\left(281,000 \mathrm{yd}^{3}\right)$ of radioactive and hazardous wastes accumulated from over 40 years of plutonium production operations are stored underground in 149 singleshell tanks and 28 double-shell tanks (Figure 3 ). Current plans are to pretreat the wastes and solidify them in a glass matrix. Pretreatment will separate the wastes into a low-radioactivity fraction, and a high-radioactivity and transuranic fraction. Most of the radionuclides will be in the high-radioactivity and transuranic fraction. Both fractions will be vitrified in separate facilities in a process that will destroy or extract organic constituents, neutralize or deactivate dangerous waste characteristics, and immobilize toxic metals. The vitrified low-radioactivity fraction will be disposed of in a near-surface facility on 


\section{Environmental Report 1994 Summary}

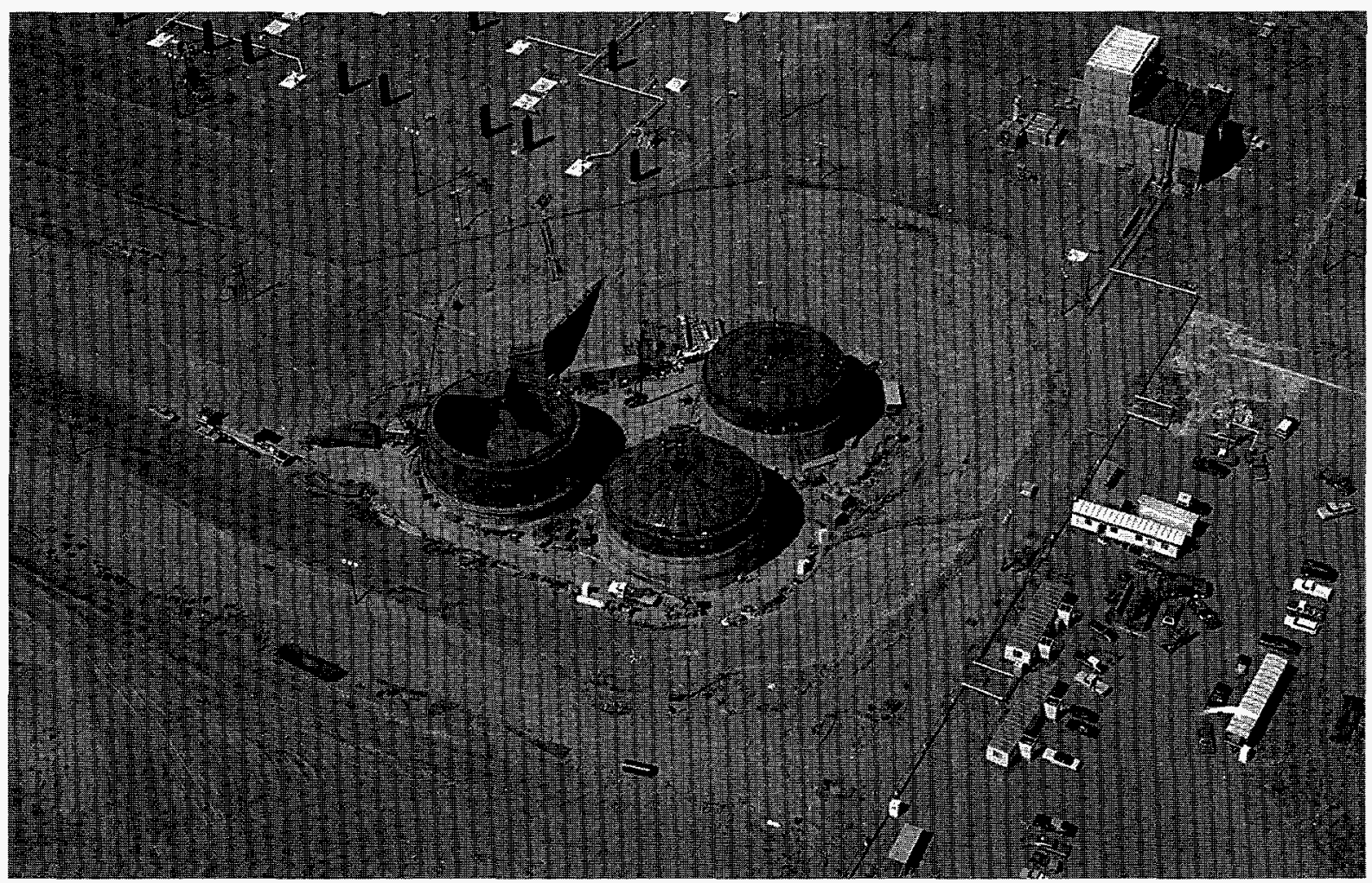

Figure 3. Three Hanford Underground Double-Shell Waste Storage Tanks Under Construction.

the Hanford Site in a retrievable form. The vitrified high-radioactivity fraction will be stored onsite until a geologic repository is available offsite for permanent disposal. Tri-Party Agreement milestones specify December 2028 for completion of pretreatment and vitrification of the tank wastes.

\section{Waste Receiving and Processing Facility}

During 1994, construction was started on the first major solid waste processing facility associated with cleanup of the Hanford Site. Scheduled to begin operations in March 1997, the Waste Receiving and Processing Facility Module 1 will be staffed to analyze, and prepare for disposal, drums and boxes of waste resulting from pluto- nium operations at Hanford. Wastes destined for this module include Hanford's current inventory of more than 37,000 drums of stored waste, as well as materials generated by future site cleanup activities. These wastes consist of primarily clothing, gloves, face masks, small tools, and dirt suspected of being contaminated with plutonium. The $0.21 \mathrm{~m}^{3}$ ( $55 \mathrm{gal}$ ) drums also may contain other radioactive materials and hazardous components. Some of the materials processed will qualify as low level waste suitable for disposal directly at the Hanford Site. The remaining wastes will be certified and packaged for eventual shipment to the Waste Isolation Pilot Plant in New Mexico. Materials requiring further processing to meet disposal criteria will be retained at Hanford pending treatment. 


\section{Hanford Site}

The 4,831 $\mathrm{m}^{2}\left(52,000 \mathrm{ft}^{2}\right)$ Waste Receiving and Processing Facility Module 1 will begin operations in 1997 near the Central Waste Complex in the 200-West Area. The 200-West Area is located on the central plateau that the public and Tri-Party agencies have designated for waste processing and long-term waste storage. The facility is designed to process 6,800 drums of waste annually for 30 years.

\section{Waste Tank Safety Issues}

In 1990, all Hanford Site high-level waste tanks were evaluated and organized into four watch list categories to ensure increased attention and monitoring. Tanks were classified as ferrocyanide, flammable gas, high-heat, and organic watch list tanks. Two other safety concerns that involve some or all of the tanks include criticality and noxious vapor safety issues.

Ferrocyanide. The ferrocyanide safety issue involves the potential for uncontrolled exothermic reactions of ferrocyanide and nitrate/nitrite mixtures. Laboratory studies show that temperatures must exceed $250^{\circ} \mathrm{C}$ for a reaction to propagate. The hottest ferrocyanide tank temperature is $53^{\circ} \mathrm{C}$ and decreasing. In October 1990 , an unreviewed safety question was declared because safety was not adequately defined by the then existing analyses. The unreviewed safety question was closed by DOE in March 1994 , as a result of significant knowledge gained from simulant studies, conservative theoretical analyses, and analyses of actual waste samples that allowed bounding safety criteria to be defined and applied to each tank. Of the 24 ferrocyanide tanks originally listed, 18 are now on the watch list. Four were rernoved in 1993, and two were removed in 1994. The remaining tanks will be taken off the watch list as core samples are obtained and analyses confirm that the ferrocyanide has decreased to acceptable levels through hydrolysis and radiolysis (aging).

Flammable Gas. The flammable gas tanks safety issue involves the potential release of flammable gases (primarily hydrogen) from wastes in selected tanks. In prior years, work controls were put in place to prevent the introduction of sources of sparks in these tanks, and evaluations were completed to ensure that installed equipment was intrinsically safe. The worst-case tank, 241-SY-101, was successfully mitigated in 1994 by inserting a mixing pump. The pump is operated up to three times a week to mix the waste and release gases that accumulate in the waste. Hydrogen monitors are being installed on all 25 flammable gas tanks.

High-Heat Tank. This safety issue concerns tank 241-C-106, a single-shell tank that requires water additions and forced ventilation for evaporative cooling. Without water additions, which would be discontinued if the tank leaked, the tank could exceed structural temperature limits and potentially result in concrete degradation and possible tank collapse. This tank is on an accelerated program for early retrieval and transfer of waste to a double-shell tank. Double-shell tanks are designed to handle heat-bearing materials better than single-shell tanks. A process test and considerable thermal analyses were completed in 1994 on tank 241-C-106 to evaluate alternative cooling approaches. The studies concluded that the tank could be adequately cooled using refrigerated air chillers.

Organic Tanks. The organic tanks safety issue involves the potential for uncontrolled exothermic reactions of organic chemicals and nitrates/ nitrites and for vapors from semivolatile organic 


\section{Environmental Report 1994 Summary}

compounds entrained in the waste to exceed flammability limits. Recent laboratory tests showed that fuel concentrations and temperatures required to support propagating exothermic reactions are comparable to those for ferrocyanide. Moisture levels above $20 \%$ will prevent reactions from propagating regardless of fuel concentrations.

Work controls were implemented in 1990 to prevent the introduction of ignition sources to these tanks. In May 1994, vapor sampling and safety analyses were completed that provided the technical basis for closing the unreviewed safety question on the flammability of the floating organic layer in tank 241-C-103. Ten tanks that contained organic complexants were added to the organic tanks watch list following a review of sampling data and waste transfer records. Other work indicates that aging processes have destroyed or significantly lowered the energy content of the organic tanks. In addition, the more energetic complexants and the primary degradation products of tributyl phosphate are water soluble in saturated nitrate-nitrite salt solutions. Thus, a high percentage of organic chemicals were removed from the single-shell tanks when their pumpable liquid supernatant was pumped out as part of the interim stabilization process for the single-shell tanks.

Criticality. The unreviewed safety question on the potential for criticality in the high-level waste tanks was closed in 1994 by completing additional analyses, strengthening tank criticality prevention controls, and improving administrative procedures and training. The analyses showed that criticality is highly unlikely during storage. All of the single- and double-shell tanks at the Hanford Site contain sufficient neutron absorbers to ensure safe storage; however, additional sampling and controls will be required for retrieval and pretreatment-related activities.

Noxious Vapor. Some of the Hanford Site tanks contain chemicals that release toxic vapors to the environment. These vapors pose a potential health risk to Hanford Site employees who work in the tank farms. The safety issue stems from an insufficient understanding of the causes of reported exposures of personnel to unacceptable levels of noxious vapors and the concern that, until the vapors in the tanks are well characterized, the risks to worker health and safety cannot be determined or controlled. In prior years, worker protection controls were instituted to prevent worker exposures, and a program was implemented for routine work space air monitoring and personnel dosimetry.

In-tank vapor sampling equipment was developed and tested in 1994. Two methods are now used to collect vapor samples from the waste tanks. The primary method involves drawing air, gases, and vapors out of the waste tanks. This method was designed to collect representative samples from warm, moist tanks, even if a fog exists in the tank headspace. A second method employs in situ sampling. Rather than transferring the air, gases, and vapors to be sampled to a remote location, the sampling devices themselves (specifically, sorbent traps) are lowered into the tank headspace. Through 1994, 18 high-level waste tanks were vapor sampled using these two methods.

Waste Tank Status. The status of the 177 waste tanks as of December 1994 is:

- Number of waste tanks

- 149 single-shell tanks

- 28 double-shell tanks 


\section{Hanford Site}

- Number of tanks listed as "assumed leaker" tanks

- 67 single-shell tanks (Tank 241-T-111 was declared an assumed releaker in 1994) - 0 double-shell tank

- Number of ferrocyanide tanks on watch list

-18 single-shell tanks (two tanks were removed from the watch list in December 1994)

- Number of flammable gas tanks on watch list -19 single-shell tanks (eight flammable gas tanks are also listed as organic tanks) -6 double-shell tanks

- Number of organic tanks on watch list -20 single-shell tanks

So far, 106 single-shell tanks have been stabilized, with the program to be completed in 2000. At the end of 1994, 98 single-shell tanks had intrusion-prevention devices completed, and 51 single-shell tanks were disconnected and capped to avoid inadvertent liquid additions to the tanks. The total estimated volume of radioactive waste leakage from single-shell tanks presently is $2,270,000$ to $3,410,000 \mathrm{~L}$ $(600,000$ to $900,000 \mathrm{gal})$.

During 1994, two single-shell tanks that were identified as assumed re-leaker tanks were pumped. In addition, six other single-shell tanks were pumped in 1994. The total liquid volume removed from the eight tanks was $490,000 \mathrm{~L}(129,000 \mathrm{gal})$.

242-A Evaporator Status. The 242-A Evaporator was operated in April 1994 to complete two waste reduction campaigns. Each campaign processed the low-level mixed waste contents of six double-shell tanks. The evaporator process resulted in an average reduction in tank waste volume of $85 \%$. The process condensate from the evaporator operation is stored in the Liquid Effluent Retention Facility and awaiting final disposal through the 200 Area Effluent Treatment Facility.

\section{Liquid Effluent Activities}

\section{Liquid Effluent Retention Facility}

Start-up activities for the Liquid Effluent Retention Facility were completed on time to support the 242-A Evaporator waste reduction campaigns in 1994. As a result of these campaigns, $25,000,000 \mathrm{~L}(6,600,000 \mathrm{gal})$ of evaporator process condensate are stored in the Liquid Effluent Retention Basins awaiting final processing through the 200 Area Effluent Treatment Facility. The Liquid Effluent Retention Facilities consist of three separate $24,600 \mathrm{~m}^{3}\left(32,200 \mathrm{yd}^{3}\right)$ storage basins (surface impoundments). Two are used for normal operation, and the third is used as a contingency should a leak develop in an operational basin.

\section{Area Effluent Treatment Facility}

The 242-A Evaporator/PUREX Plant Process Condensate Treatment Facility (200 Area Effluent Treatment Facility) is being constructed to provide effluent treatment and disposal capability required to restart the 242-A Evaporator for future campaigns. The facility will provide for effluent collection, a treatment system to reduce the concentration of radioactive and hazardous waste constituents in the effluent streams to acceptable levels, tanks to allow verification of treated effluent characteristics before discharge, and a state-approved land disposal structure for 


\section{Environmental Report 1994 Summary}

effluents. Secondary waste generated by the treatment facility will be concentrated and packaged to meet state requirements for storage and/or disposal of solid waste. Acceptance testing of the facility began in late 1994 .

\section{Area Treated Effluent Disposal Facility}

The 200 Area Treated Effluent Disposal Facility will be a permitted system for the collection, sampling, and disposal of 13 effluent streams in the 200-East and 200-West Areas. Effluents will meet the requirements of the best available technology before being discharged to the collection and disposal system. Construction of the collection system began in April 1993 and is now complete; final testing of the system is ongoing. The disposal facility design is complete.

\section{Area Treated Effluent Disposal Facility}

The 300 Area Treated Effluent Disposal Facility was completed and in operation in December 1994, ahead of schedule and under budget. A National Pollutant Discharge Elimination System permit has been issued by EPA Region 10 that allows the facility to discharge treated effluents to the Columbia River. The permit contains a reopener clause such that after one year of operation, permit conditions may be renegotiated.

\section{Miscellaneous Effluent Streams}

The DOE Richland Operations Office committed to submit State Waste-Water Discharge Permit applications for eleven miscellaneous effluent streams. A decision was made to instead obtain a National Pollutant Discharge Elimination
System permit for two of these streams (300 Area Powerhouse ash waste water and filter backwash) to discharge to the Columbia River. Other changes included the decision to connect the 300 Area sanitary sewer to the City of Richland publicly owned treatment works, and the decision to connect the 234-5Z ventilation steam condensate/dry air compressor cooling water to the 200 Area Treated Effluent Disposal Facility. The 209-E Building steam condensate stream was eliminated. State wastewater discharge permit applications were submitted to the Washington State Department of Ecology in June 1994 for the remaining six miscellaneous streams.

The DOE Richland Operations Office also agreed to inventory the remaining miscellaneous effluent streams and to develop a plan and schedule for their disposition. An inventory of all effluent streams was developed that identified more than 500 small discharges. These discharges were evaluated against criteria developed to determine if they had any potential to cause harm to the environment or ground water. This inventory and these criteria were used to develop the final overall plan and schedule for regulatory compliance, which was submitted to Washington State Department of Ecology in December 1994.

\section{Environmental Monitoring}

Environmental monitoring of the Hanford Site consists of 1) effluent monitoring and 2) environmental surveillance, which includes groundwater monitoring. Effluent monitoring is performed as appropriate by the operators at the facility or at the point of release to the environment. Additional monitoring is conducted in the environment near facilities that currently discharge effluents or have discharged them in the 


\section{Hanford Site}

past. Environmental surveillance consists of sampling and analyzing environmental media on and off the Hanford Site to detect and quantify potential contaminants and to assess their significance to the environment and human health.

The overall objectives of the monitoring and surveillance programs are to demonstrate compliance with applicable federal, state, and local regulations; confirm adherence to $D O E$ environmental protection policies; and support environmental management decisions.

\section{Effluent Monitoring}

Effluent monitoring includes facility effluent monitoring (monitoring effluents at the point of release to the environment) and near-facility environmental monitoring (monitoring the environment near operating facilities).

Facility Effluent Monitoring. Facility operators monitor effluents mainly through analyzing samples collected near points of release into the environment. Measuring devices are used to establish most facility effluent flow rates. In some cases flow rates are calculated using process information. Liquid and gaseous effluents with a potential to contain radioactive materials at prescribed threshold levels are monitored for total alpha and total beta activity and, as warranted, for other specific radionuclides. Nonradioactive hazardous constituents are also monitored, as appropriate.

Radioactive effluents from many facilities are approaching levels practically indistinguishable from the naturally occurring radioactive materials present everywhere. Totals of radionuclides in effluents released at the Site in 1994 are not significantly different from totals in 1993.

\section{Near-Facility Environmental Monitoring.}

The near-facility environmental monitoring program monitored new and existing sites, processes, and facilities for potential impacts and releases; fugitive emissions and diffuse sources from contaminated areas; and surplus facilities before decontaminating or decommissioning. External radiation dose, ambient air particulates, soil, surface water, sediment, and biota were measured and sampled. Parameters measured included, as appropriate, radionuclides, radiation exposure, hazardous constituents, $\mathrm{pH}$, and water temperature.

The analytical results showed a large degree of variability; in general, the samples collected from media located on or directly adjacent to the waste disposal and other nuclear facilities had significantly higher concentrations than those farther away. As expected, certain radio-nuclides were found in higher concentrations within different operational areas. Generally, the predominant radionuclides consisted of activation products/gamma emitters in the 100 Areas (e.g., cobalt-60), fission products in the 200/600 Areas (e.g., strontium-90, cesium-137), and uranium in the 300 Area.

Near-Facility Air Monitoring. Radioactivity in air was sampled by a network of continuously operated samplers at 41 locations near facilities. Air samplers were primarily located at or near sites and/or facilities having the potential or history for release, with an emphasis on the prevailing downwind directions. Of the radionuclide analyses performed, cesium-137, plutonium-239,240, strontium-90, and uranium were consistently detectable in the 200 Areas; cobalt-60 was detectable in the 100-N Area. Air concentrations for these radionuclides were 


\section{Environmental Report 1994 Summary}

elevated near facilities when compared to concentrations measured offsite.

\section{Monitoring of Surface-Water Disposal Units and Springs. Radiological analysis of liquid samples from surface-water disposal units included plutonium-239,240, total alpha, total beta, tritium, and gamma-emitting radionu- clides. Radiological analysis of sediment and aquatic vegetation included plutonium-239,240, strontium-90, uranium, and gamma-emitting radionuclides. Nonradiological analysis per- formed included $\mathrm{pH}$, temperature, and nitrate.}

Radionuclide concentrations in surface-water disposal units were below the applicable Derived Concentration Guides used as indexes of performance and in most cases were at or below the analytical detection limit. Although some elevated levels were seen in both aquatic vegetation and sediment, in all cases the analytical results were well below the standards for radiological control. The results for $\mathrm{pH}$ were well within the $\mathrm{pH}$ range of $2.0-12.5$, which is the standard for liquid effluent discharges as required by the Resource Conservation and Recovery Act. The analytical results for nitrate were all below the 45-mg/L Drinking Water Standard.

Ground-water springs along the 100-N Area shoreline were sampled to verify the reported radionuclide releases to the Columbia River from past operations of the N Reactor. Reported releases into the river are calculated based on analyses of samples collected weekly from a monitoring well located near the river shoreline and down gradient of the 100-N Area Liquid Waste Disposal Facilities (Figure 4). The release is calculated by multiplying the conservatively high radionuclide concentrations from the monitoring well by the estimated N-Springs ground-water discharge into the river. The ground-water discharge rate was calculated using a computer model and was estimated to be $38 \mathrm{~L} / \mathrm{min}$ $(10 \mathrm{gal} / \mathrm{min})$ in 1994 .

In 1994, concentrations detected in the springs samples were highest for springs nearest the facility effluent monitoring well, although the springs concentrations were considerably lower than concentrations measured in the well.

Near-Facility Radiological Surveys. There were approximately 2,756 hectares (6,364 acres) of land posted to warn of surface contamination and 981 hectares (2,423 acres) of land posted to warn of underground radioactive materials sitewide in 1994. These areas were typically associated with cribs, burial grounds, tank farms, and covered ponds, trenches, and ditches. The number of posted surface contamination areas varied because of an ongoing effort to clean, stabilize, and remediate areas of known contamination while new areas of contamination were being identified. New areas may have been identified because of migrating contamination or the increased effort to investigate outdoor areas for radiological contamination. The external dose rate for $80 \%$ of the identified outdoor surface contamination areas was estimated to be less than $1 \mathrm{mrem} /$ hour, although isolated radioactive particles (less than $0.6 \mathrm{~cm}$ [0.25 in.] in diameter) could be considerably higher. Such levels of contamination would not add significantly to external dose rates for the public or Site employees.

Soil and Vegetation Monitoring. Soil and vegetation samples were also collected on or adjacent to waste disposal units and from locations downwind and within the operating environment of facilities. Special samples were taken where physical or biological transport problems were identified. 


\section{Hanford Site}

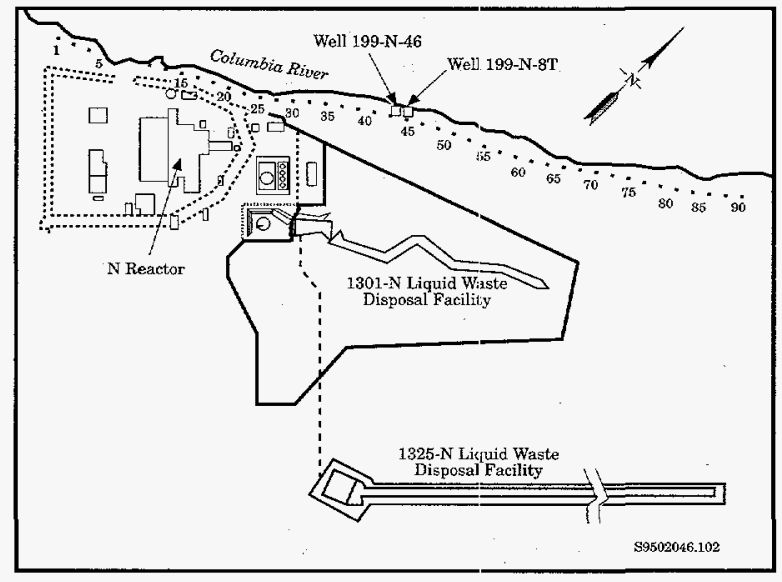

Figure 4. Sampling and Survey Locations Along the 100-N Shoreline.

Results were variable; in general, samples collected on or directly adjacent to waste disposal facilities had significantly higher concentrations than those collected farther away.

Investigative Sampling. Investigative sampling was conducted in the operations areas to monitor for radioactive or hazardous contaminants. Samples were collected where known or suspected radioactive contamination was present, or to verify radiological conditions at project sites. The types of samples collected included air, water, soil, vegetation, freshwater clams, snakes, birds, mice, bird nests, and coyote feces. In 1994, 52 samples were analyzed for radionuclides, and 23 showed some level of contamination. An additional 42 areas of contamination were discovered during cleanup operations and were appropriately cleaned up without collecting samples for isotopic analysis.

External Radiation. Hand-held microroentgen meters (to measure low-level radiation exposure) were used in the 100-N Area to survey points near and within the $\mathrm{N}$-Springs area, $1301-\mathrm{N}$
Liquid Waste Disposal Facility, and 1325-N Liquid Waste Disposal Facility.

The radiation rates measured in the $\mathrm{N}$-Springs area continued to decline in 1994, reflecting the shutdown of the 1301-N Liquid Waste Disposal Facility and the continuing decay of its radionuclide inventory. Radiation measurements taken at the 1325-N Liquid Waste Disposal Facility in 1994 and in the previous years were slightly elevated. Because discharges to the facility have been discontinued, water that formerly provided shielding for the gamma-emitting radionuclides in sediments of the facility has been lost.

Radiation levels measured with thermoluminescent dosimeters were highest near facilities that had contained or received liquid effluent from N Reactor, primarily the 1325-N Liquid Waste Disposal Facility and the 1301-N Liquid Waste Disposal Facility. Dose rates for 1994 for these two facilities decreased approximately $5 \%$ compared to 1993. However, thermoluminescent dosimeter measurements can fluctuate $10 \%$ or more because of variations in natural background radiation.

The highest dose rates measured in the 200/600 Areas were near waste-handling facilities such as tank farms. The average annual dose rate for 1994 in the 200/600 Areas was $160 \mathrm{mrem} /$ year, which was a decrease of $6 \%$ compared to 1993.

The highest dose rates measured in the 300 Area were near waste-handling facilities such as the 340 Waste Handling Facility. The average annual dose rate for 1994 in the 300 Area was 170 $\mathrm{mrem} /$ year, which was a $15 \%$ decrease from the average dose rate of $200 \mathrm{mrem} / \mathrm{year}$ measured in 1993. 


\section{Environmental Report 1994 Summary}

The highest dose rates measured in the 400 Area were near the main gate of the Fuels and Materials Examination Facility. The average annual dose rate for 1994 in the 400 Area was $110 \mathrm{mrem} /$ year, which was an increase of $12 \%$ over the average annual dose rate of 98 mrem/year in 1993.

\section{Environmental Surveillance}

Environmental surveillance encompasses sampling and analyzing for potential radiological and nonradiological chemical (referred to here as chemical) contaminants on and off the Hanford Site. Emphasis is placed on surveillance of exposure pathways and chemical constituents that present the greatest potential risk to the public and the environment.

The environmental surveillance program focuses on routine releases from DOE facilities on the Hanford Site; however, the program is also responsive to unplanned releases and releases from non-DOE operations on and near the Site.

Objectives. Key surveillance objectives in 1994 included verifying compliance with DOE and EPA radiological dose standards for public protection, independently assessing the adequacy of facility pollution controls, assessing the environmental and public health impacts of Hanford operations, identifying and quantifying potential environmental quality problems, and providing information for environmental management of the Site to DOE, the public, and regulatory agencies.

Surveillance Design. The primary pathways for movement of radioactive materials and chemicals from the Site to the public are the atmosphere and surface water (Figure 5).
The significance of each exposure pathway is determined by measuring and estimating amounts of radioactive materials or chemicals transported along each pathway and by comparing contaminant concentrations or radiological doses to environmental and public health protection standards or guides. The results of calculations based on effluent data show that radiological and chemical concentrations in the environment off of the Hanford Site are low and generally below the level that can be detected by current monitoring technology. To ensure that radiological and chemical analyses of samples are sufficiently sensitive, minimum detectable concentrations of key radionuclides and chemicals in air, water, and food are established at levels well below the levels associated with applicable health standards.

Surveillance is conducted using established written procedures. Laboratory analyses of samples for radioactivity and chemicals were conducted in 1994 principally by International Technology Corporation and PNNL, both in Richland, Washington. Selected river water quality and chemistry analyses, and temperature and flow measurements were performed by the U.S. Geological Survey.

Air Surveillance. Radioactive materials in air were sampled continuously at 36 locations onsite, at the Site perimeter, in nearby and distant communities, and at three communityoperated environmental surveillance stations that were managed and operated by local school teachers. At all locations, particulates were filtered from the air and analyzed for radionuclides. Air was sampled and analyzed for selected gaseous radionuclides at key locations. Several radionuclides released at the Hanford Site are also found worldwide from two other sources: 


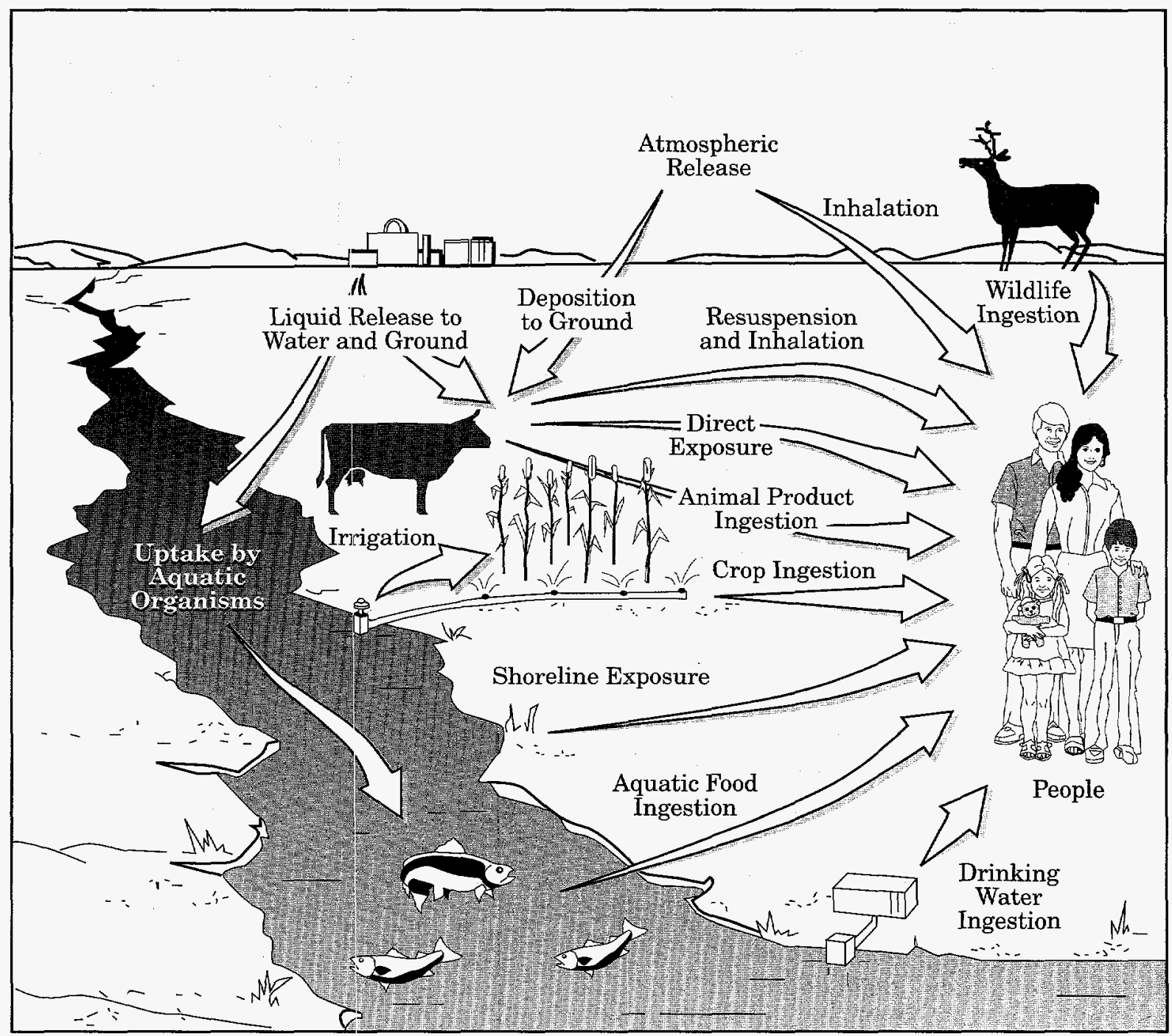

Figure 5. Primary Exposure Pathways.

S9203058.131C

naturally occurring radionuclides and radioactive fallout from historical nuclear activities not associated with Hanford. The potential influence of emissions from Site activities on local radionuclide concentrations was evaluated by comparing differences between concentrations measured at distant locations within the region and concentrations measured at the Site perimeter.
In 1994, no differences were observed between the annual average total beta air concentrations measured at the Site perimeter and those measured at distant community locations. Air concentrations of total alpha were slightly elevated at the Site perimeter, and concentrations at nearby communities were within the range of historical values. Numerous specific radionuclides in quarterly composite samples were analyzed using gamma scan analysis; 


\section{Environmental Report 1994 Summary}

however, no radionuclides of Hanford origin were detected consistently.

Tritium concentrations for 1994 were elevated for two individual samples but consistently elevated concentrations were not seen at any location, and there was little difference between concentrations at the distant locations and those at the Site perimeter.

Air concentrations of plutonium-238, and 239,240 , and strontium-90 for samples collected both onsite and offsite were below detection limits. Average uranium concentrations in airborne particulate matter were similar at the Site perimeter and distant locations.

lodine-129 concentrations were statistically elevated at the Site perimeter compared to distant locations indicating a measurable Hanford source (Figure 6); however, the average concentration at the Site perimeter was only $0.000002 \%$ of the Derived Concentration Guide of $70 \mathrm{pCi} / \mathrm{m}^{3}$. The Derived Concentration Guide is the air concentration that would result in a radiation dose equal to the DOE public dose limit (100 mrem/year).

Air samples were collected at several Hanford Site locations for volatile organic compounds. All measured air concentrations of these organic compounds were well below applicable occupational maximum allowable concentration standards for air contaminants. No ambient air standards currently exist for these compounds.

Surface-Water Surveillance. Although radionuclides associated with Hanford operations continued to be routinely identified in Columbia River water during the year (Figure 7), concentrations remained extremely low at all locations and were well below applicable standards. Concentrations

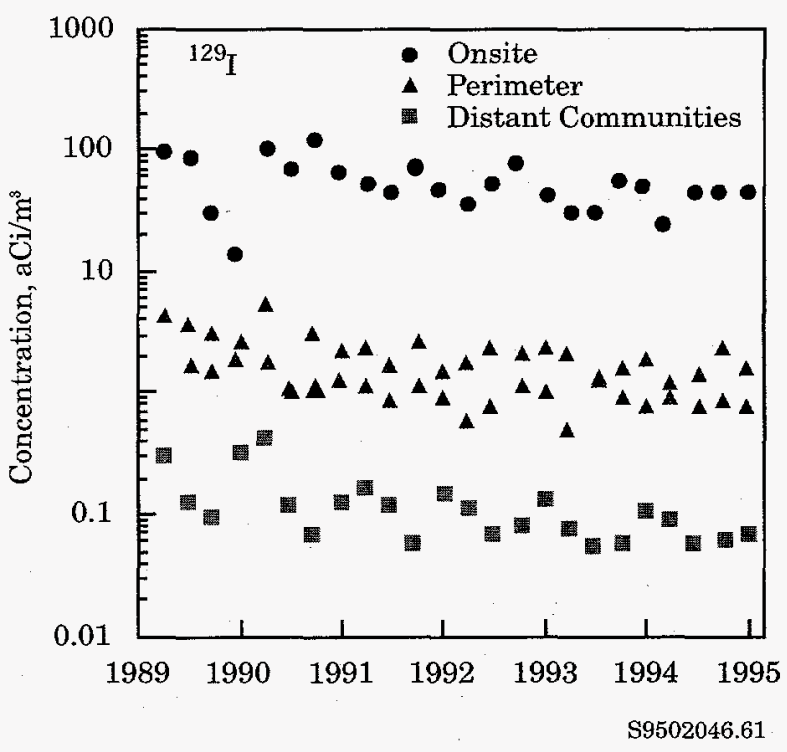

Figure 6. Concentration of lodine-129 in Air, 1989

Through 1994.

of tritium were significantly higher ( $5 \%$ significance level) at the Richland Pumphouse (downstream from the Site) than at Priest Rapids Dam (upstream from the Site) indicating a contribution from ground-water flow into the river along the Hanford Reach (Figure 8). The highest tritium concentrations were observed near the shoreline of the old Hanford Townsite. The upstream and downstream concentrations of all other monitored radionuclides were not significantly different. For chemical water quality constituents measured in Columbia River water during 1994, metals and anions were generally similar upstream and downstream and in compliance with applicable primary drinking water standards. Concentrations of volatile organic compounds were generally below analytical detection levels.

During 1994, samples were collected from seven Columbia River shoreline springs that contained contaminants as a result of past waste disposal practices at the Hanford Site. Contaminant concentrations in the springs were similar to those 


\section{Hanford Site}

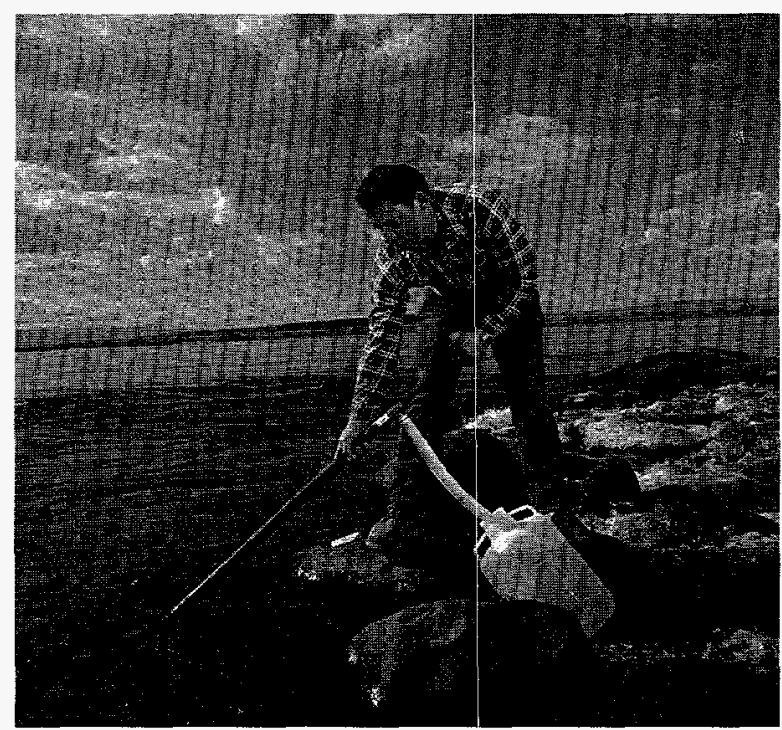

Figure 7. Water Sampling from the Columbia River Shoreline.

found in the ground water. One way to assess the impact of radionuclides in nori-potable springs water is to compare concentrations to state and federal Drinking Water Standards and DOE's Derived Concentration Guides. All radionuclide concentrations measured in riverbank springs in 1994 were less than applicable DOE Derived Concentration Guides. However, concentrations of strontium-90 in the 100-D and 100-H Areas, tritium in the 100-N Area and along the old Hanford Townsite (Figure 9), and total alpha in the 300 Area exceeded Washington State and federal Drinking Water Standards. Concentrations of total uranium exceeded the Site-specific proposed EPA Drinking Water Standard in the 300 Area. The only chemical contaminants measured in non-potable riverbank springs water in 1994 that exceeded Drinking Water Standards were chromium and nitrate in the 100-D Area spring. During 1994, samples of Columbia River surface sediments were collected from behind McNary Dam (downstream from the Site) and Priest Rapids Dam (upstream from the Site) and from four shoreline locations along the Hanford Reach of the Columbia River. These samples were analyzed for selected radionuclides and metals. As in the past, radionuclide concentrations in sediments behind McNary Dam were generally higher than those observed in sediments collected from behind Priest Rapids Dam and along the Site. With the exception of the chromium concentration, which was slightly elevated in sediments along the Hanford Reach, mean metal concentrations along the Hanford Reach and at McNary Dam were not significantly different (based on the standard error of the mean) from those at Priest Rapids Dam.

Three onsite ponds were sampled to determine radionuclide concentrations. These ponds are accessible to migratory waterfowl and other animals. As a result, a potential biological path-

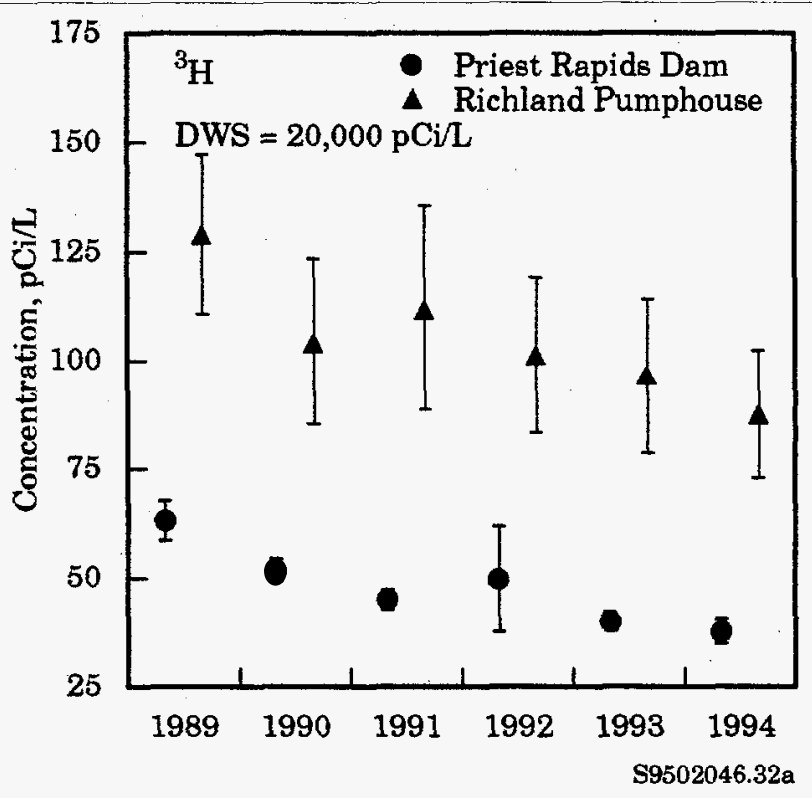

Figure 8. Annual Average Tritium Concentrations ( \pm 2 Standard Error of the Mean) in Columbia River Water, 1989 Through 1994. As a result of figure scale, some uncertainties (error bars) are concealed by point symbols. 


\section{Environmental Report 1994 Summary}

way exists for the removal and dispersal of contaminants that may be in the ponds. Concentrations of radionuclides in water collected from these ponds during 1994 were similar to those observed during past years. With the exception of uranium-234 and uranium-238 in the July sample of West Lake, radionuclide concentrations in the onsite pond water were below applicable DOE Derived Concentration Guides. It is believed that suspended sediments in the West Lake sample were responsible for the elevated uranium results.

Offsite water, used for irrigation and/or drinking water, was sampled in 1994 to determine radionuclide concentrations in water used by the nearby public. Elevated total alpha and total beta concentrations, attributed to naturally occurring uranium, were observed at some locations. All radionuclide concentrations measured in offsite water supplies and irrigation water were below applicable DOE Derived Concentration Guides and applicable Drinking Water Standards. The proposed EPA Drinking Water Standard for total uranium, however, was exceeded at one location. Radionuclide concentrations in offsite irrigation water were similar to those observed in the Columbia River.

Soil and Vegetation Surveillance. In 1994, 20 surface soil samples were collected on and off the Hanford Site. Radionuclides potentially originating from Hanford Site operations that were consistently detected in soil samples were cesium-137, plutonium-239,240, strontium-90, and uranium238. Potential Hanford impacts were evaluated by comparing onsite and offsite results. Concentrations at onsite and offsite locations were similar. In 1994, perennial vegetation was sampled at four onsite, one distant, and four perimeter locations. Vegetation results were compared using the same rationale as for soil sampling. Radionuclides

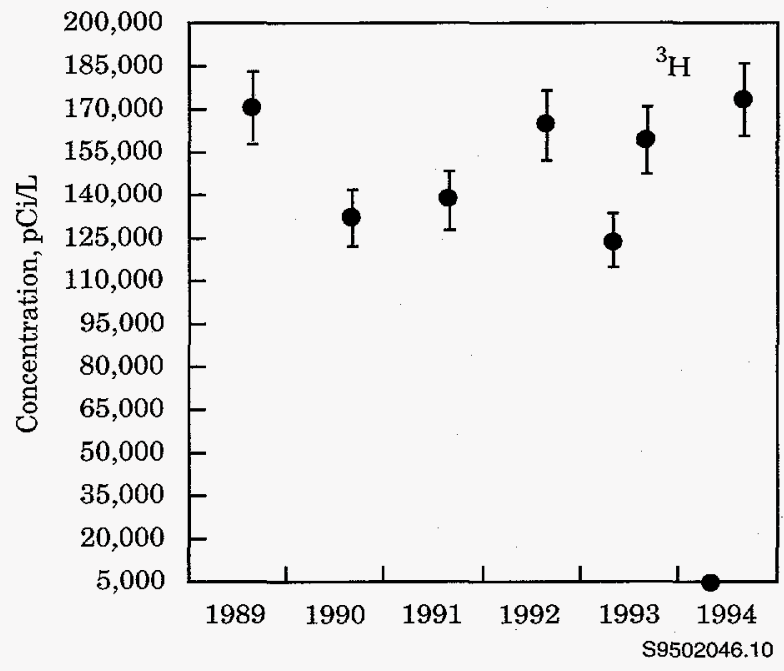

Figure 9. Tritium Concentrations ( \pm 2 total propagated analytical uncertainty) in Riverbank Spring Water Near the Old Hanford Townsite, 1989 Through 1994. As a result of figure scale, some uncertainties (error bars) are concealed by point symbols.

potentially originating from Hanford Site operations that were consistently detected in vegetation samples were strontium-90, uranium-238, and plutonium-239,240. Cesium-137 was also detected in four of the nine samples. A significant statistical difference was noted between cesium-137 concentrations at onsite and perimeter locations and offsite and onsite locations (concentrations were higher onsite). A significant statistical difference was also seen in uranium238 concentrations in samples collected on and off the Site (concentrations were higher onsite). In a special study of Columbia River milfoil, a nuisance aquatic plant, slightly elevated concentrations of uranium-238 were found in plants growing near the 300 Area. No offsite accumulation of radionuclides of Hanford origin was identifiable from the soil and vegetation samples collected and analyzed in 1994. 


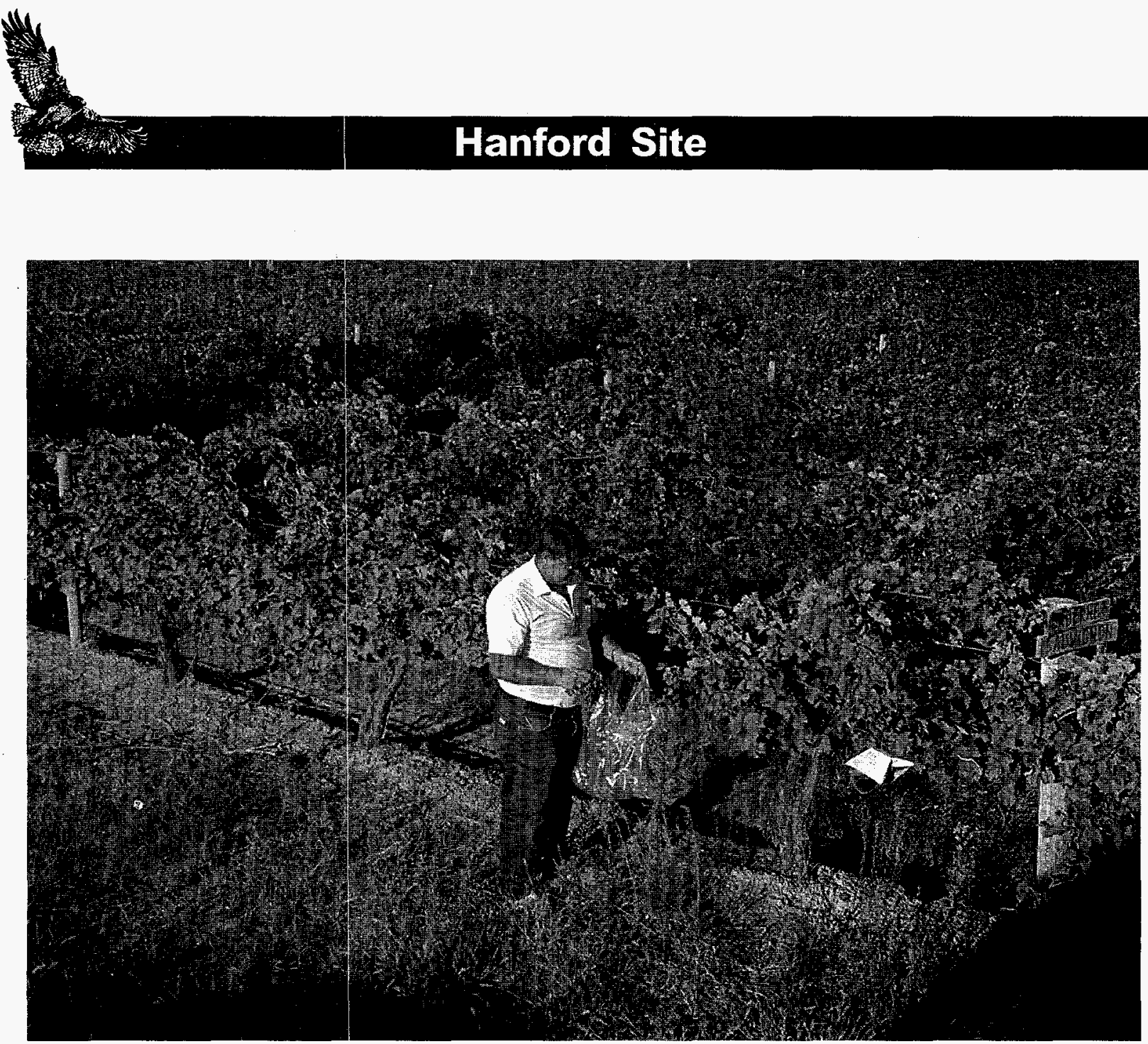

Figure 10. Agriculture Sampling Near Hanford.

Fish and Wildlife Surveillance. Analysis of wildlife for radionuclides indicated that some species had accumulated levels of radioactive materials greater than background levels.

Strontium-90 was detected in deer and rabbit bone and in Columbia River fish carcasses at levels exceeding concentrations reported in background locations. Cesium- 137 concentrations were higher in the muscle of deer collected in 1992 from a background location in Stevens County, north of Spokane, than concentrations observed in Hanford Site populations of mule deer. The levels of cesium-137 in the deer from Stevens County were attributed to past atmospheric fallout from weapons testing. Collectively, the levels of radionuclides measured in Hanford fish and wildlife indicate accumulation of small amounts of specific radionuclides originating from the Hanford Site.

Food and Farm Product Surveillance. The Hanford Site is situated in a large agricultural area that produces a wide variety of food products and alfalfa. Milk, eggs, poultry, beef, vegetables, fruit, wheat, alfalfa, and wine were collected from areas generally downwind from the Site, upwind of the Site, and at distant locations (Figure 10). Alfalfa and farm products were analyzed for cesium-137, cobalt-60, iodine129, plutonium-238, plutonium-239,240, strontium $=90$, technetium-99, tritium, and uranium isotopes. 


\section{Environmental Report 1994 Summary}

Most of the farm products sampled did not contain measurable concentrations of radionuclides. Tritium was measured at levels very close to the detection level in wine, but no apparent upwind or downwind effect was noted lodine-129 was found at slightly elevated levels in milk samples from downwind locations, but the levels were very low and have been decreasing over the past 6 years. Concentrations of strontium-90 in alfalfa were slightly elevated (relative to background concentrations) in samples collected from fields irrigated with water drawn from the Columbia River downstream from Hanford.

External Radiation Surveillance. In 1994, radiological dose rates were measured at a number of locations on and off the Hanford Site using thermoluminescent dosimeters. Contributors to the radiological doses measured included natural (uranium, thorium and their progeny in soil and other primordial radionuclides) and artificial sources.

The average background radiological dose rate, calculated from thermoluminescent dosimeters at Yakima and Sunnyside (locations distant and upwind relative to Hanford), was $96 \pm 8 \mathrm{mrem} /$ year compared to the average downwind perimeter dose rate of $110 \pm 9 \mathrm{mrem} /$ year (Figure 11). Dose rates at the Columbia River shoreline near the 100-N Area were approximately two times the typical shoreline dose rates. The higher dose rates may be attributable to radiation from the 100-N Area liquid waste disposal facilities. Onsite dose rates measured near operational areas were slightly higher than the average background dose rate.

\section{Ground-Water Surveillance}

Ground-water surveillance at the Hanford Site is conducted to assess radiological and hazardous chemical impacts of Hanford activities on ground water, to provide an integrated assessment of ground-water quality on the Hanford Site, and to evaluate potential offsite impacts. In addition to the sitewide monitoring activities performed for environmental surveillance, near-field groundwater monitoring is performed to evaluate the effects of operations in and around specific waste-disposal facilities.

Objectives. Ground-water surveillance objectives include verifying compliance with applicable environmental laws and regulations; verifying compliance with environmental commitments made in environmental impact statements, environmental assessments, safety analysis reports, or other official DOE documents; characterizing and defining trends in the physical, chemical, and biological condition of environmental media; establishing environmental quality baselines; providing a continuing assessment of pollution abatement programs; and identifying and quantifying new or existing environmental quality problems.

Design. Ground-water samples are collected from wells completed in the unconfined and upper-confined aquifers. The unconfined aquifer is monitored extensively because it has been contaminated from Hanford operations and provides a pathway for contaminants to reach points of human exposure (e.g., onsite water supply wells, Columbia River). The upperconfined aquifer is monitored, although less extensively than the unconfined aquifer, because it also provides a potential pathway for contaminants to migrate off the Hanford Site. 


\section{Hanford Site}

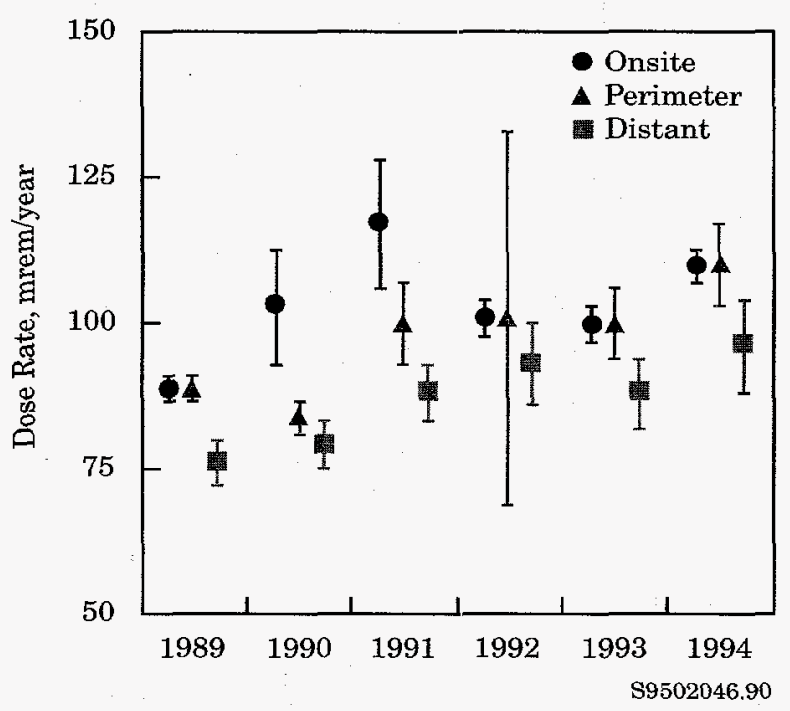

Figure 11. Annual Average Dose Rates $( \pm 2$ standard error of the mean), 1989 Through 1994.

Contaminant source areas are monitored to characterize and define trends in the chemical condition of the ground water and to identify and quantify existing, emerging, or potential ground water quality problems. Source areas include regions with active waste disposal facilities or with facilities that have generated or received waste in the past. These include the 100,200 , and 300 Areas on the Site as well as the central landfill. Ground-water monitoring in these areas is performed primarily by the Site operating contractor under Resource Conservation and Recovery Act compliance or operational monitoring programs. Additional sampling is conducted by the Environmental Restoration Contractor Team as part of activities of the Comprehensive Environmental Response, Compensation, and Recovery Act on the Hanford Site. Wells located within known contaminant plumes continue to be monitored to characterize and define trends in the concentrations of the associated radiological or chemical constituents. These wells are also monitored to quantify existing ground water quality problems and to provide a baseline of environmental conditions against which future changes can be assessed.

Water supplies on and near the Site potentially provide the most direct route for human exposure to contaminants in ground water. Three water supplies exist onsite. One is for staff and visitors at the Fast Flux Test Facility, one is at the Yakima Barricade guard house, and one is at the Hanford Patrol shooting range. Water supply wells for the City of Richland are adjacent to Hanford's southern boundary. Wells near these water systems are monitored to identify any potential water quality problems long before regulatory limits are reached.

Wells are also monitored to assess the quality of ground water at the Site perimeter. Wells in a region about $2-\mathrm{km}$-wide $(1.2 \mathrm{mi})$ along the southern boundary of the Site have been identified for monitoring.

To determine the impact of Hanford operations on the environment, the background conditions, or the quality of water on the Hanford Site unaffected by operations, must be known. Data on the concentrations of contaminants of concern present in ground water before Hanford operations are not available; therefore, the best estimate of pre-Hanford operations ground-water quality is provided by the concentrations of naturally occurring chemical and radiological constituents in ground water sampled from wells located in areas unaffected by Hanford operations, including upgradient locations. Samples are collected at various frequencies depending on the historical trends of constituent data, regulatory compliance requirements, and characterization requirements. Sampling frequencies range from monthly to annually; some 


\section{Environmental Report 1994 Summary}

constituents are monitored less frequently than annually in some wells.

\section{Ground-Water Protection and Monitoring.} During 1994, approximately 800 Hanford Site wells were sampled to satisfy ground-water monitoring needs.

Radiological monitoring results indicated that cesium-137, cobalt- 60 , iodine-129, strontium90, technetium-99, total alpha, total beta, tritium, and uranium were detected in levels greater than the Drinking Water Standard (i.e., at concentrations that would result in a 4 -mrem per year dose to the total body or any organ) in one or more wells onsite. Plutonium concentrations were also slightly elevated in one well. Concentrations of tritium greater than the Derived Concentration Guide were detected in the 200 Areas. The Derived Concentration Guide is the water concentration that would result in a radiation dose equal to the DOE public dose limit of 100 mrem per year. Concentrations of strontium-90 greater than the Derived Concentration Guide were detected in the 100-N Area and 200-East Area. Concentrations of uranium greater than the Derived Concentration Guide were detected in the 200-West Area. Plutonium concentrations greater than the Derived Concentration Guide were detected in the 200-East Area.

Extensive tritium plumes extend from the 200-East and 200-West Areas into the 600 Area. The plume from the 200-East Area extends east and southeast, discharging to the Columbia River. This plume has impacted tritium concentrations in the 300 Area but at levels less than the Drinking Water Standard. The spread of this plume farther south than the 300 Area is restricted by the ground-water flow away from the Yakima River and the North Richland well field. Ground water with tritium at levels above the Drinking Water Standard also discharges to the Columbia River in the 100-N Area and immediate vicinity. A small but high-concentration tritium plume near the $100-\mathrm{K}$ East Reactor also may discharge to the river. Tritium at levels greater than the Drinking Water Standard was also found in the 100-D and 100-F Areas.

Cobalt- 60 was detected in the northeastern part of the 200-East Area and parts of the surrounding 600 Area but at levels less than the Drinking Water Standard. Cobalt-60 concentrations at levels greater than the Drinking Water Standard in the 100-N Area appear to be related to suspended sediments in the samples and are not indicative of ground-water concentrations.

Concentrations of strontium-90 at levels greater than the Derived Concentration Guide were measured in the 100-N Area. This plume discharges to the Columbia River. Ground water in a localized area in the 200-East Area also contains strontium-90 at levels greater than the Derived Concentration Guide. Strontium-90 at levels greater than the Drinking Water Standard were found in the 100-B, 100-F, 100- $\mathrm{H}$, and 100-K Areas. These plumes extend to the Columbia River. Only one well in the 100-D Area showed strontium-90 at levels greater than the Drinking Water Standard.

Technetium-99 was found at concentrations greater than the Drinking Water Standard in the northeastern part of the 200-East Area and adjacent 600 Area. Technetium-99 was also detected at levels greater than the Drinking Water Standard in the 200-West Area and in adjoining parts of the 600 Area. 


\section{Hanford Site}

lodine-129 was detected at levels greater than the Drinking Water Standard in the 200-East Area and in an extensive part of the 600 Area to the east and southeast. The iodine-129 and tritium share common sources; however, there is no indication that iodine-129 is present at concentrations greater than the Drinking Water Standard in the ground water currently discharging to the Columbia River. lodine-129 at levels greater than the Drinking Water Standard also extends into the 600 Area to the northwest of the 200-East Area. The southern part of the 200-West Area is also a source of iodine-129 extending into the 600 Area. There is a less extensive iodine-129 plume at levels greater than the Drinking Water Standard in the northcentral part of the 200-West Area.

Cesium-137 was detected only in the 200-East Area. The concentrations detected were greater than the Drinking Water Standard but were restricted to the immediate vicinity of one well.

Uranium was detected at levels greater than the EPA proposed Drinking Water Standard in wells in the 100-F, 100-H, 200-East, 200-West, and 300 Areas. Ground water with uranium concentrations greater than the proposed Drinking Water Standard appears to be discharging to the Columbia River from the $100-\mathrm{H}$ and 300 Areas. One well in the 200-West Area had concentrations greater than the Derived Concentration Guide.

Plutonium was only detected in ground-water samples near one well in the 200-East Area. There is no explicit Drinking Water Standard for plutonium; however, the levels were greater than the Drinking Water Standard for gross alpha.
Certain nonradioactive chemicals regulated by the EPA and the state of Washington were also present in Hanford Site ground water. These constituents were also characterized by the monitoring programs.

Nitrate concentrations exceeded the Drinking Water Standard at locations in all 100 Areas with the exception of the 100-B Area. Nitrate from the 200-East Area extends east and southeast in the same area as the tritium plume. Nitrate from sources in the northwestern part of the 200-East Area is present in the adjacent 600 Area at levels greater than the Drinking Water Standard. Nitrate is present at levels greater than the Drinking Water Standard in the 200-West Area and adjoining 600 Area locations. Some of the nitrate in the 600 Area, 1100 Area, and North Richland area is believed to result from offsite sources.

Fluoride was measured at levels greater than the primary Drinking Water Standard in the 200-West Area.

Chromium was found at levels greater than the Drinking Water Standard in the 100-D, 100-H, 100-F, and 100-K Areas.

An extensive plume of carbon tetrachloride at levels greater than the Drinking Water Standard was found in ground water at the 200 -West Area and extended into the 600 Area. This plume is associated with a less extensive plume of chloroform that may be a degradation product of the carbon tetrachloride. Maximum chloroform levels are also greater than the Drinking Water Standard.

Trichloroethylene was found at levels greater than the Drinking Water Standard in the 100-F Area and in the 600 Area to the west. Trichloroet- 


\section{Environmental Report 1994 Summary}

hylene was also detected at levels greater than the Drinking Water Standard in the 300 Area, 100-K Area, and 200-West Area.

\section{Additional Environmental Programs}

\section{Meteorological Studies}

Meteorological measurements are taken at Hanford to support Site emergency preparedness, Site operations, and atmospheric dispersion calculations. Weather forecasting and the maintenance and distribution of climatological data are provided.

The Hanford Meteorological Station is located on the 200 Area Plateau where the prevailing wind direction is from the northwest during all months. The secondary wind direction is from the southwest. The average wind speed for 1994 was $11.8 \mathrm{~km}$ per hour (7.3 mph), which was slightly less than normal, and the peak gust for the year was $84 \mathrm{~km}$ per hour (52 mph).

Precipitation for 1994 totaled $15.6 \mathrm{~cm}$ (6.1 in.), $98 \%$ of normal, with $13.2 \mathrm{~cm}$ (5.2 in.) of snow recorded.

Temperatures for 1994 ranged from $-15.0^{\circ} \mathrm{C}$ $\left(5^{\circ} \mathrm{F}\right)$ in February to $43.9^{\circ} \mathrm{C}\left(111^{\circ} \mathrm{F}\right)$ in July.

\section{Wildlife Studies}

Wildlife inhabiting the Hanford Site was monitored to determine the status and condition of the populations and to assess effects of Hanford Site operations (Figure 12). Particular attention was focused on species that are rare, threatened, or endangered nationally or statewide and those species that are of commercial, recreational, or aesthetic importance statewide or locally. These species include the bald eagle, Chinook salmon, Rocky Mountain elk, mule deer, Canada goose, several species of hawk, and other bird species. Fluctuations in the numbers of wildlife and plant species on the Hanford Site appear to be a result of natural ecological factors and management of the Columbia River system.

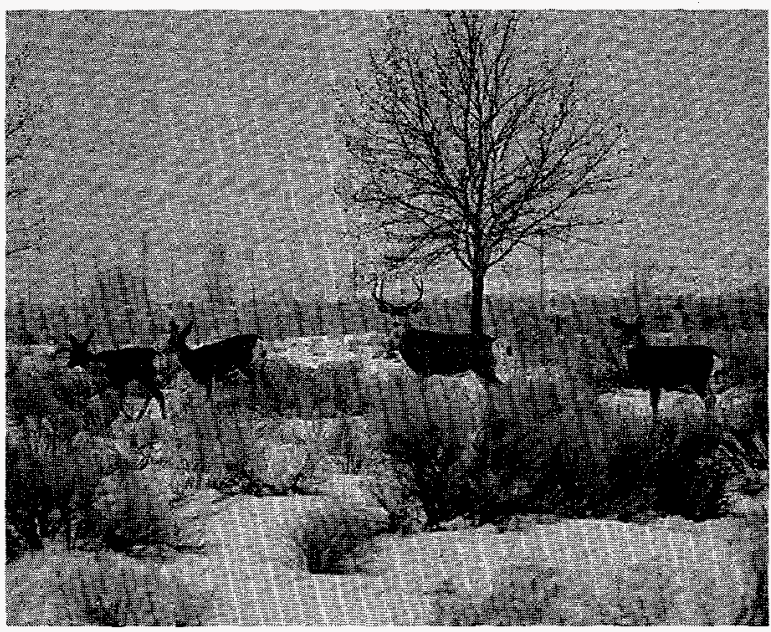

Figure 12. Wildlife on the Hanford Site.

\section{Cultural Resources Program}

The Hanford Cultural Resources Laboratory was established in 1987 by the Richland Operations Office as part of the Pacific Northwest National Laboratory. Cultural resources on the Hanford Site are closely monitored, and projects are relocated to avoid cultural resource sites whenever there is a possibility of altering any properties that may be eligible for listing on the National Register of Historic Places.

Erosive processes and human activities apparently are the most significant factors affecting most sites and buildings. Wind erosion, resulting from off-road vehicle use, and vandalism cause deterioration of sites both inside and outside the Site boundary while alteration or demolition 


\section{Hanford Site}

activities cause impacts to buildings and/or structures.

\section{Community Involvement in Environmental Sampling}

The community-operated environmental surveillance program was initiated in 1990 to increase public involvement in, and awvareness of, Hanford's surveillance program. Three surveillance stations continued operation in 1994, and construction of a new station at Heritage College in Toppenish, Washington began. Other expansion activities were also started.

\section{Potential Radiation Doses from 1994 Hanford Operations}

To the extent possible, radiation dose assessments should be based on direct measurements of radiation dose rates and radionuclide concentrations in environmental media. However, the amounts of most radioactive materials released from Hanford operations in recent years generally have been too small to be measured directly once the materials are dispersed in the offsite environment. For measurable radionuclides, it is often impossible to distinguish levels resulting from worldwide fallout and natural sources from those associated with Hanford releases. Therefore, offsite doses in 1994 were estimated by applying environmental transport and dose calculation models to measured effluent monitoring data and selected environmental measurements.

The potential dose to the hypothetical maximally exposed individual in 1994 from Hanford operations was $0.05 \mathrm{mrem}\left(5 \times 10^{-4} \mathrm{mSv}\right)$, compared to 0.03 mrem $\left(3 \times 10^{-4} \mathrm{mSv}\right)$ calculated for 1993 . The small additional dose in 1994 resulted from increased concentrations of uranium isotopes in
Columbia River water collected downstream of the Hanford Site and from continued releases of radon isotopes from research laboratories in the 300 Area. The potential dose to the local population of 380,000 persons from 1994 operations was 0.6 person-rem ( 0.006 person-Sv), compared to 0.4 person-rem (0.004 person-Sv) reported for 1993 . The 1994 average dose to the population was $0.002 \mathrm{mrem}\left(2 \times 10^{-5} \mathrm{mSv}\right)$ per person. The current DOE radiation limit for an individual member of the public is $100 \mathrm{mrem} /$ year (1 mSv/year), and the national average dose from natural sources is $300 \mathrm{mrem} /$ year ( $3 \mathrm{mSv} /$ year). The maximally exposed individual potentially received a dose from Hanford sources that was $0.05 \%$ of the DOE dose limit and $0.02 \%$ of the national average background dose from natural sources. The average individual potentially received a dose from Hanford sources that was $0.002 \%$ of the standard and $0.0005 \%$ of the $300 \mathrm{mrem} /$ year received from typical natural sources. At the location of the maximally exposed individual, the estimated potential dose from Hanford through the air pathways (monitored stack emissions) was $0.1 \%$ of the EPA limit of $10 \mathrm{mrem} /$ year.

\section{Maximum Boundary Dose Rate}

The "boundary" radiation dose rate is the external radiation dose rate measured at publicly accessible locations on or near the Site. The boundary dose rate was determined from radiation exposure measurements obtained using TLDs at locations of expected elevated dose rates onsite and at locations offsite. These boundary dose rates should not be used to calculate annual doses to the general public because no one actually resides at any of these boundary locations. However, these rates can be used to determine the dose to a specific individual who 


\section{Environmental Report 1994 Summary}

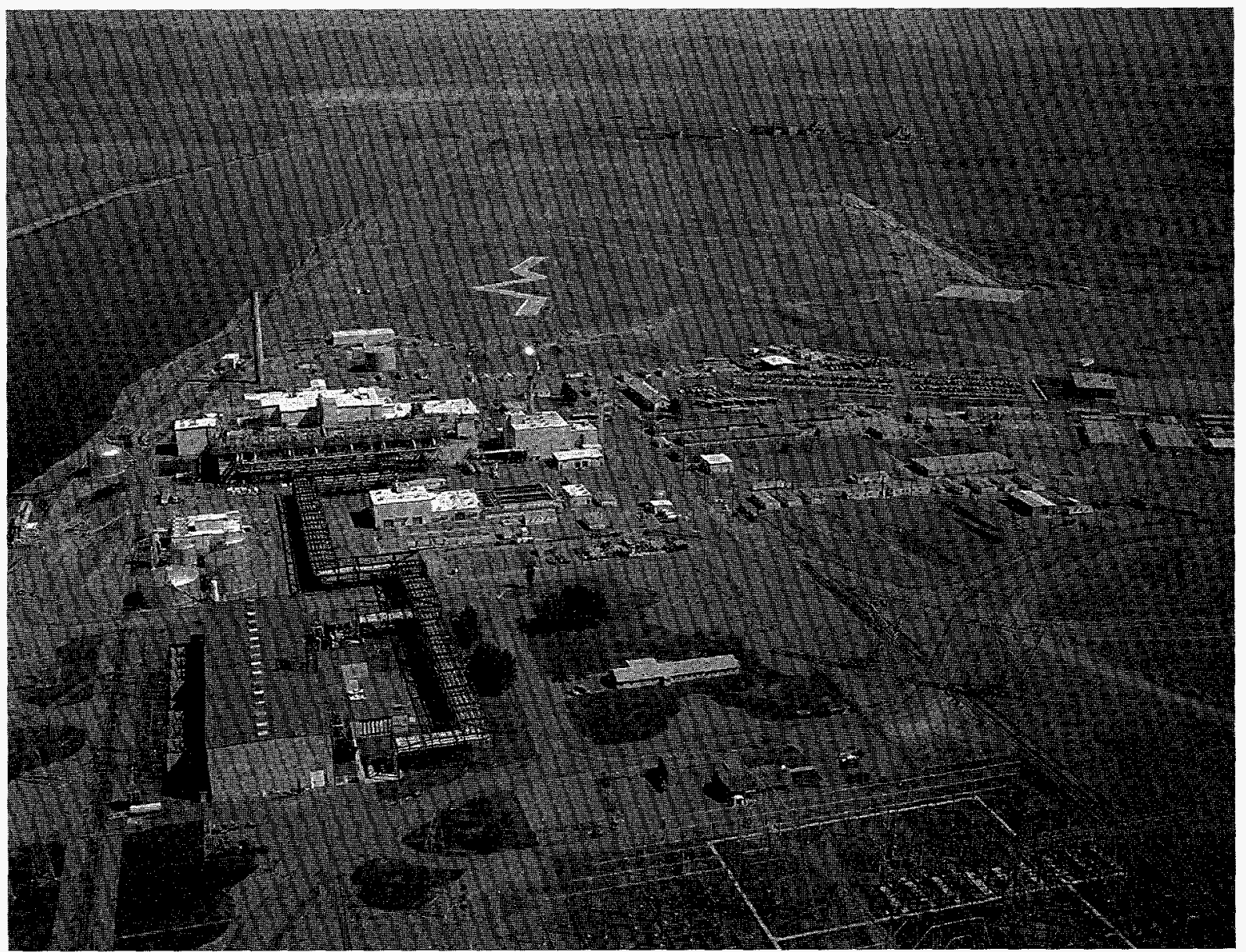

Figure 13. The N Reactor Complex Located Along the Columbia River Shoreline.

might have spent some time at that location.

The annual average dose rate at the location with the highest exposure rate along the 100-N shoreline (Figure 13) during 1994 was 0.03 $\mathrm{mrem} / \mathrm{h}\left(3 \times 10^{-4} \mathrm{mSv} / \mathrm{h}\right)$, or about $0.02 \mathrm{mrem} / \mathrm{h}$ $\left(2 \times 10^{-4} \mathrm{mSv} / \mathrm{h}\right)$ above the average background dose rate of $0.01 \mathrm{mrem} / \mathrm{h}\left(1 \times 10^{-4} \mathrm{mSv} / \mathrm{h}\right)$ normally observed at offsite shoreline locations. Therefore, for every hour someone spent at the 100-N Area shoreline during 1994, the external radiation dose received from Hanford operations would be about $0.02 \mathrm{mrem}\left(2 \times 10^{-4} \mathrm{mSv}\right)$. The public can approach the $100-\mathrm{N}$ shoreline by boat, but legally is restricted from stepping onto the shoreline.

The Fast Flux Test Facility Visitors Center, located southeast of the Test Facility reactor building, was opened to the public during the first 9 months of 1994. Dose rates measured at this location continued to be essentially equal to normal background radiation levels in the vicinity of Hanford $\left(0.01 \mathrm{mrem} / \mathrm{h}\left[1 \times 10^{-4} \mathrm{mSv} / \mathrm{h}\right]\right)$. 


\section{Hanford Site}

\section{Sportsman Dose}

Wildlife have access to areas of the Site that contain contamination and could become contaminated. The potential also exists for contaminated wildlife to move offsite. For this reason, sampling is conducted onsite to estimate the maximum contamination that could exist in animals hunted offsite. This is a unique and relatively low probability scenario that is not included in the maximally exposed individual calculation.

Listed below are examples of the estimated radiation doses that could have resulted if onsite wildlife containing the maximum concentrations measured in 1994 migrated offsite and were hunted and consumed. These are very low doses, and the significance of this pathway is further reduced because wildlife migration offsite is relatively small, and onsite wildlife is relatively inaccessible to hunters. Not all of the maximum values were observed in the same animal of each species sampled. However, the maximum values were compounded to arrive at an upper limit to the potential concentrations. The dose from eating $1 \mathrm{~kg}$ (2.2 lbs) of meat containing the maximum concentration of cesium-137 measured in a deer collected onsite is estimated to be $4 \times 10^{-4} \mathrm{mrem}\left(4 \times 10^{-6} \mathrm{mSv}\right)$. The dose from eating $1 \mathrm{~kg}$ ( $2.2 \mathrm{lbs})$ of meat containing the maximum concentrations of cesium-137 and cobalt- 60 measured in any ganne bird collected onsite is estimated to be $8 \times 10^{-3} \mathrm{mrem}\left(8 \times 10^{-5}\right.$ $\mathrm{mSv}$ ). The dose from eating $1 \mathrm{~kg}(2.2 \mathrm{lbs})$ of meat containing the maximum concentration of cesium-137 measured in a rabbit collected onsite is estimated to be $2 \times 10^{-3} \mathrm{mrem}\left(2 \times 10^{-5} \mathrm{mSv}\right)$. The dose from eating $1 \mathrm{~kg}$ (2.2 lbs) of meat containing the maximum concentrations of cesium- 137 and cobalt- 60 measured in bass, whitefish, or carp collected from the Hanford Reach of the Columbia River is estimated to be $7 \times 10^{-3} \mathrm{mrem}\left(7 \times 10^{-5} \mathrm{mSv}\right)$. The dose from eating $1 \mathrm{~kg}$ (2.2 lbs) of meat containing the concentrations of uranium isotopes measured in a composite sample of small Asiatic clams collected from the Columbia River downstream of the 300 Area is estimated to be $2 \times 10^{-2} \mathrm{mrem}$ $\left(2 \times 10^{-4} \mathrm{mSv}\right)$.

\section{Comparison with Clean Air Act Standards}

The limits for radiation dose to the public from airborne emissions at DOE facilities specify that no member of the public shall receive a dose of more than $10 \mathrm{mrem} / \mathrm{yr}(0.1 \mathrm{mSv} / \mathrm{yr})$ from exposure to airborne radionuclide effluents (other than radon) released at DOE facilities. Each DOE facility is required to submit an annual report that supplies information about atmospheric emissions for the preceding year and their potential offsite impacts.

During 1994, the dose to the maximally exposed individual across the river from the 300 Area was 0.05 mrem $\left(5 \times 10^{-4} \mathrm{mSv}\right)$, which was greater than the estimated dose at that location from stack emissions (0.01 mrem or $1 \times 10^{-4} \mathrm{mSv}$ ). Doses at other locations around the Hanford Site perimeter ranged from 0.02 to 0.08 mrem ( $2 \times 10^{-4}$ to $8 \times 10^{-4} \mathrm{mSv}$ ). Based on these results, the combined dose from stack emissions and diffuse and unmonitored sources during 1994 was much less than the EPA standard.

\section{Hanford Public Radiation Dose in Perspective}

Although no increase in the incidence of health effects from low doses of radiation has actually 


\section{Environmental Report 1994 Summary}

been confirmed by the scientific community, most scientists accept the conservative hypothesis that low-level doses might increase the probability that certain types of effects, such as cancer, could occur. Regulatory agencies conservatively (cautiously) assume that the probability of these types of health effects at low doses (down to zero) is proportional to the probability of these same health effects observed historically at much higher doses (in atomic bomb victims, radium dial painters, etc.). Therefore, using conservative assumptions, it is postulated that even the natural background radiation (which is many hundreds of times greater than radiation from current Hanford releases) increases each person's probability or chance of developing a detrimental health effect.

Scientists do not agree about how to translate the available data on health effects into the numerical probability (risk) of detrimental effects from low-level radiation doses. Because cancer and hereditary diseases in the general population may be caused by a multitude of sources (e.g., genetic defects, sunlight, chemicals, and background radiation), some scientists doubt that the risk from low-level radiation exposure can ever be determined accurately. In developing Clean Air Act regulations, the EPA has used a probability value of approximately 4 per 10 million $\left(4 \times 10^{-7}\right)$ for the risk of developing a fatal cancer after receiving a dose of $1 \mathrm{mrem}(0.01 \mathrm{mSv})$. Recent data support the reduction of even this small risk value, possibly to zero, for certain types of radiation when the dose is spread over an extended time.

Government agencies are trying to determine what level of risk is safe for members of the public exposed to pollutants from industrial activities (for example, DOE facilities, nuclear power plants, chemical plants, and hazardous waste sites). All of these industrial activities are considered beneficiai to people in some way, such as providing electricity, national defense, waste disposal, and consumer products. These government agencies have a complex task in establishing environmental regulations that control levels of risk to the public without unnecessarily reducing the needed benefits from industry.

\section{Quality Assurance}

Comprehensive quality assurance (QA) programs, which include various quality control practices and methods to verify data, are maintained to ensure data quality. The QA programs are implemented through QA plans designed to meet requirements in the American National Standards Institute/American Society of Mechanical Engineers NQA-1 QA program document and DOE Orders. Quality assurance plans are maintained for all activities, and auditors verify conformance. Quality control methods include, but are not limited to, replicate sampling and analysis, analysis of field blanks and blind reference standards, participation in interlaboratory cross-check studies, and splitting samples with other laboratories. Sample collection and laboratory analyses are conducted using documented and approved procedures. When sample results are received, they are screened for anomalous values by comparing them to recent results and historical data. Analytical laboratory performance on the submitted double-blind samples, the EPA Laboratory Intercomparison Studies Program, and the national DOE Quality Assessment Program indicated that laboratory performance was adequate overall, was excellent in some areas, and needed improvement in others. 
Acknowledgments

We thank K.R. Price, Pacific Northwest National Laboratory, for providing the historical informaion on Hanford Site operations, and Craig Sarto, Boeing Computer Services, Richland for providing the design and layout. 